Thematic Review

\title{
Targeting mitotic pathways for endocrine-related cancer therapeutics
}

\author{
Shivangi Agarwal and Dileep Varma \\ Department of Cell and Molecular Biology, Feinberg School of Medicine, Northwestern University, \\ Chicago, Illinois, USA
}

Correspondence should be addressed to D Varma Email dileep.varma@northwestern. edu

\begin{abstract}
A colossal amount of basic research over the past few decades has provided unprecedented insights into the highly complex process of cell division. There is an ever-expanding catalog of proteins that orchestrate, participate and coordinate in the exquisite processes of spindle formation, chromosome dynamics and the formation and regulation of kinetochore microtubule attachments. Use of classical microtubule poisons has still been widely and often successfully used to combat a variety of cancers, but their non-selective interference in other crucial physiologic processes necessitate the identification of novel druggable components specific to the cell cycle/division pathway. Considering cell cycle deregulation, unscheduled proliferation, genomic instability and chromosomal instability as a hallmark of tumor cells, there lies an enormous untapped terrain that needs to be unearthed before a drug can pave its way from bench to bedside. This review attempts to systematically summarize the advances made in this context so far with an emphasis on endocrine-related cancers and the avenues for future progress to target mitotic mechanisms in an effort to combat these dreadful cancers.
\end{abstract}

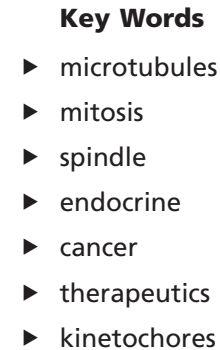

Endocrine-Related Cancer (2017) 24, T65-T82

\section{Cytoskeleton: structure and dynamics of microtubules}

The human cytoskeleton plays a crucial role in maintaining cellular shape, motility of the cell as a whole and motility of organelles within the cell. Three discrete components make up the cytoskeleton: microfilaments $(6 \mathrm{~nm}$, actin), microtubules $(25 \mathrm{~nm})$ and intermediate filaments $(10 \mathrm{~nm}$, keratin, vimentin, lamin, desmin, etc.) (Fletcher \& Mullins 2010). A common feature these components share is that they are made up of repeating, self-assembling and disassembling building blocks called as subunits, culminating in highly dynamic filamentous structural networks necessary for a diverse array of biological functions including cell growth, rapid cell division (cytokinesis), chromosomal segregation, ciliary/ flagellar movements, intracellular vesicular transport and uptake of material and signals from extracellular milieu
(Nogales 2001). This review aims to focus on microtubules as a cytoskeletal component, its allied roles in mitosis and the key conceptual advances in the field over this period, with a spotlight on its impact on the field of cancer therapeutics.

Microtubules (MTs) are polarized long hollow cylindrical structures comprising of $\alpha$ - and $\beta$-tubulin heterodimers. These heterodimers of $50 \mathrm{kDa}$ each share $50 \%$ identity at amino acid level, assemble in a headto-tail fashion in a reversible non-covalent manner to generate protofilament; 13 of such protofilaments associate longitudinally and close up to form a MT (Akhmanova \& Steinmetz 2015). These structures are highly organized yet dynamic i.e. their ends constantly experience a lengthening (polymerization) and a

This paper forms part of a special section on 50 Years of Tubulin. The Guest Editors for this section were Karen Crasta and Ritu Aneja. 
shortening (depolymerization) process (Desai \& Mitchison 1997). This process termed as 'dynamic instability' is highly regulated and is governed by the nucleotide-binding ability of tubulin dimers facilitating an active GTP/GDP exchange (Mitchison \& Kirschner 1984). The $\alpha$-tubulin binds to GTP acquiring a conformation amenable to MT polymerization, whereas $\beta$-tubulin can bind either to GTP or GDP favoring MT polymerization or depolymerization, respectively (Alushin et al. 2014). The MT end can be distinguished as plus (+) end if the MT is terminated by a $\beta$-tubulin protein or a minus (-) end when the MT closes with an $\alpha$-tubulin subunit. Therefore, each end has a distinct characteristic that imparts structural and kinetic polarity and determines the stability. Tubulin addition and removal are much faster at the plus end than at the microtubule minus end, which is embedded in the centrosome or microtubule organizing center (MTOC) (Tran et al. 1997). A second form of dynamic behavior exhibited by the microtubules is 'treadmilling', which implies net growth at MT plus end and net shortening at the minus end (Margolis \& Wilson 1978).

In humans, MTs exist in combinations of at least thirteen $\alpha$ - and $\beta$-tubulin isotypes (encoded by different genes) displaying specific cell, tissue and developmental distribution (Cleveland \& Sullivan 1985). These isotypes are classified based on their high degree of sequence divergence at the carboxy (C)-termini (15-20 amino acids), which interestingly are also the hot-spots for the binding of microtubule-associated proteins (MAPs) and extensive post-translational modifications (PTMs, acetylation, tyrosination/detyrosination, poly/de-glutamylation, polyglycylation, phosphorylation, palmitoylation). This confers further chemical diversity, variability and unique functionality to each isotype (Janke \& Bulinski 2011). It is well established that both these aspects (PTMs and MAPs) significantly modulate MT dynamics (Sirajuddin et al. 2014).

\section{Janus with two faces: tubulin, both as a cause of and a cure for cancer}

MTs are key to the success of mitosis, one of the most dramatic and crucial cellular functions. Mitosis entails effective and bonafide partitioning of replicated chromosomes among the daughter cells. In interphase, MTs exchange their tubulin with the soluble tubulin pool relatively slower (half time of several min to hours) compared to the half time of 10-30s during mitosis (Saxton et al. 1984). At the onset of mitosis, the interphase MT array completely disassembles and is supplanted by a network of remodeled bipolar spindle, which is 10- to 100-fold more dynamic (characterized by both dynamic instability and treadmilling) than the MTs of interphase cytoskeleton (Rusan et al. 2001). After the nuclear envelope breakdown, MT dynamics is fundamental to the attachment of chromosome to the spindles in prometaphase, movement of chromosomes to the metaphase plate followed by their proper alignment and synchronous chromosomal segregation in anaphase (Mitchison 1988). Thus, to successfully locate every unattached chromosome, MTs undertake several extensive excursions, growing long distances, followed by shortening and then re-growing until they successfully establish stable connection with the chromosomes (Hayden et al. 1990). Considering MTs to be the key machinery driving the entire mitotic process, drugs that bind tubulin, referred to as 'tubulin-binding agents' (TBA) or microtubule targeting agents (MTA) represent soft target for the development of anti-cancer drugs (Mukhtar et al. 2014). Overall, one class of inhibitors operate by sequestering tubulin monomers and thus inhibiting polymerization of tubulin to form MTs. Colchicine analogs and vinca alkaloids (vinblastine, vincristine, vinorelbine, vindesine, vinflunine) are such polymerization inhibitors. The other class of inhibitors like paclitaxel analogs (docitaxel/ taxotere, epithilones, discodermolide and eleutherobins) block the depolymerization of polymerized tubulin, function as microtubule-stabilizing agents and are called depolymerization inhibitors (Jordan 2002). These drugs are extremely successful and promising as chemotherapeutic drugs for combating both hematopoietic and solid tumors (Zelnak 2007). Although the mechanism of action of these mitotic poisons in each category and even within the category differ in terms of their binding site and mode of action (Mukhtar et al. 2014), at the cellular level, both these classes of drugs exert their effect by inducing mitotic arrest and cell death (Mollinedo \& Gajate 2003).

Although MTs serve as spectacular target for various cancer treatments, there is an interesting second face to this fact. A multitude of diverse alterations in tubulin/MTs have been identified and exhaustively characterized as the cause for different varieties of cancers. This is generally attributed to aberrant expression of tubulin isotypes, erroneous post-translational modification of tubulin or differential expression of MAPs. $\alpha$-Tubulin acetylation and detyrosination (by tubulin carboxypeptidase, TCP) are increased in breast cancer cell lines and tissues leading to tumor aggressiveness and poor prognosis 
in patients (Boggs et al. 2015). TTL (tyrosine ligase), an enzyme responsible for re-tyrosination of tubulin, was observed to be suppressed during tumor growth in mice (Lafanechere et al. 1998). In fact, various PTMs in tubulin are correlated with tumor growth and enhanced metastasis including prostate and pancreatic cancers (Soucek et al. 2006, Kashiwaya et al. 2010, Wasylyk et al. 2010, CastroCastro et al. 2012, Maiato et al. 2017). Because of their correlation with cancer, targeting PTMs represent a viable approach for targeting these altered cancer cells. Indeed, compounds such as parthenolide (an inhibitor of TCP (Fonrose et al. 2007)) and its more soluble derivative suitable for oral and plasma use, DMAPT, have yielded moderate success in clinical trials either alone or in combination with taxanes or vinca alkaloids (Curry et al. 2004, Sweeney et al. 2005, Shanmugam et al. 2010, Ghantous et al. 2013).

Interestingly, these alterations not only contribute to tumorigenesis but also function as another major mechanism underlying non-responsiveness of cancer cells to MTAs, besides the intrinsic or acquired drug resistance involving overexpression of drug-efflux pumps (Kavallaris et al. 2001). The overexpression of $\beta I I I-$ and $\beta I V a-t u b u l i n$ isotype has been correlated with ovarian and prostate cancers and at the same time these tumors were resistant to commonly used MT-targeting therapeutics (Ranganathan et al. 1996, Kavallaris et al. 1997, Dozier et al. 2003, Mozzetti et al. 2005). Similarly, differential expression of MAPs has also been documented to interfere with MTAs; for example, overexpression of a MT-stabilizing protein MAP4 was found to enhance MT stability and counteract the MT-destabilizing drugs such as vinca alkaloids (Kavallaris et al. 2001).

Distinct from the $\alpha$ and $\beta$ subunits of tubulin that compose the MTs, there is a third type of tubulin called as $\gamma$-tubulin, which in association with other proteins form a conical shaped structure, $\gamma$-tubulin ring complex ( $\gamma$-TuRC) (Oakley et al. 2015). This complex not only provides a scaffold or template for $\alpha / \beta$ tubulin dimers during the nucleation process but also caps the (-) end while the MT continues to grow from its (+) end. This cap provides both stability and protection to the MT (-) end from depolymerizing enzymes, simultaneously inhibiting the (-) end growth (Job et al. 2003). BRCA1 (breast cancer 1 gene) is an E3-ubiquitin ligase that ubiquitinates Lys48 in $\gamma$-tubulin and inhibits MT nucleation thereby regulating centrosome number in cells (Sankaran et al. 2005). BRCA1 is breast- and ovary-specific tumor suppressor gene and its expression is reduced in the majority (55\%) of sporadic epithelial ovarian cancers (EOCs), which is the most common type representing approximately $90 \%$ of ovarian cancers (Sun et al. 2013). In serous ovarian carcinomas, which is a sub-category constituting about 2/3rd of EOCs, low BRCA1 expression occurs in more than $50 \%$ of cases (McMillen et al. 2012). Thus, in the event of loss of BRCA1 in breast cancers, centrosomes undergo hypertrophy leading to aneuploidy (Lingle et al. 1998). BRCA1 also influences sensitivity of breast cancer cells to MTAs, for instance, a BRCA1 mutant cell line is more sensitive to vinorelbine, a vinca alkaloid, compared to the cell lines with wild-type allele (Tassone et al. 2005).

Thus, in light of these issues, to combat refractory tumors and to outwit the multifactorial drug resistance, there is a pressing need to either (a) intensively search for and design new pharmacological small compounds that can bind to other domains within the tubulin by utilizing advancements in crystallographic techniques or (b) to identify new targets besides microtubules/tubulin system, an open avenue that merits further exploration. Since targeting the ubiquitously essential targets like tubulin will dampen the therapeutics window dramatically, the next generation of therapeutics should capitalize on targeting the components unique to the oncogenic cells or exclusive pathways that are either active or defective in the cancer cells such that the healthy cells are unaffected and effects can be exacerbated in the targeted cancerous cells. Examples of such targets and their contribution in the allied cellular processes are shown in Fig. 1.

\section{Unexplored arenas for potential development of novel cancer therapeutics}

\section{Kinetochore-microtubule (kMT) interface}

One of the most striking features of cancer cells is chromosomal abnormalities referred to as aneuploidy, resulting from an erosion of mitotic fidelity leading to chromosomal instability (CIN). Aneuploidy and CIN both are attributed to poor patient prognosis, metastasis and resistance to chemotherapies (Thompson \& Compton 2011). Therefore, as described previously, the process of cell division logically and rationally represents an extraordinary target to develop antitumor therapies. Indeed, myriad of clinically relevant anti-tubulin drugs have proven quite effective against a wide range of tumors. However, they not only suffer drug resistance but also collateral effects, such as myelosuppression and MT disruption in non-dividing tissues, including brain (Jordan \& Wilson 2004). Consequently, the kinetochores (KTs) and the peripheral proteins that participate in the

Published by Bioscientifica Ltd 
Interphase

Mitosis (M-phase)

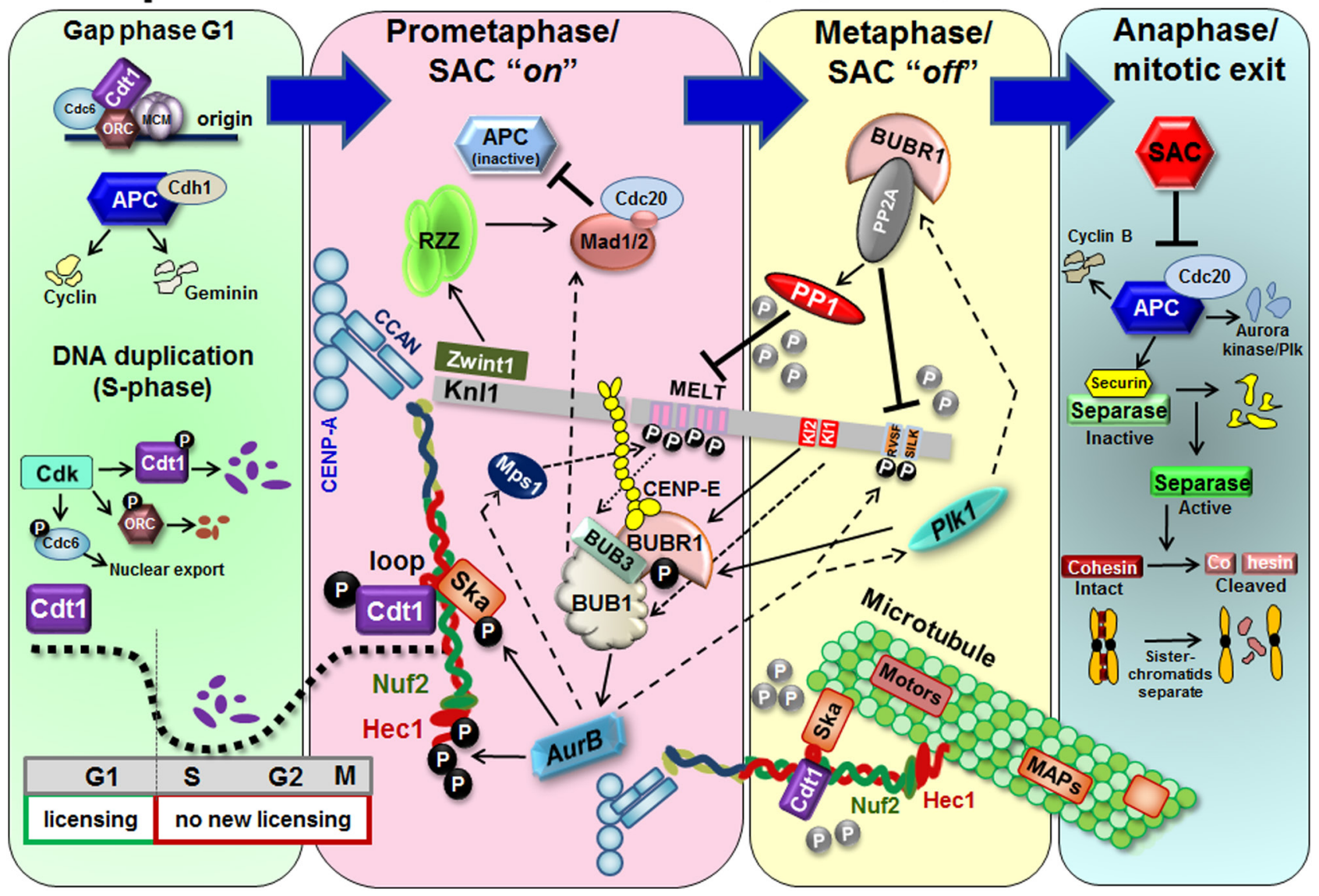

Figure 1

A schematic representation of cell cycle progression and the crucial components that are currently targeted at the various stages or can be exploited in the future for anti-cancer therapy. (1) The ORC, Cdc6 and Cdt1 assemble to form the pre-replicative complex (pre-RC) necessary to load the presumptive MCM replicative helicase, a process called as replication licensing. From late mitotic phase (M) to $\mathrm{G} 1$ phase, two critical inhibitors of the pre-RC formation, Cdk and geminin are suppressed by APC/C ubiquitin ligase that targets them for proteolysis through polyubiquitination (Fujita 2006). At the onset of S-phase, Cdk becomes active (by APC/C inactivation) and functions to obliterate the re-establishment of pre-RC and re-licensing during the S, G2 and M phases of the cell cycle (Fujita 2006). This is accomplished by Cdk-mediated phosphorylation of Cdc6 followed by its nuclear export, phosphorylation and degradation of ORC and Cdt1 (Fujita 2006). After S-phase, geminin also accumulates that sequesters Cdt1 by direct binding. Cdt1 however re-accumulates post G2-/M-phase in phosphorylated state where it contributes in maintaining robust kMT attachments via its interaction with the Hec1 loop. (2) The kinetochore proteins start to assemble through the recognition of centromeres enriched with the CENP-A (centromere-associated protein-A) containing nucleosomes that marks it as the site for kinetochore formation. In early prometaphase or prophase, the KMN network, especially the Knl1 protein along with Zwint-1 serves to recruit several checkpoint proteins like Mad1, Mad2, Mps1 kinase, Bub1, Bub3, the RZZ complex, BubR1 and CENP-E to the unattached kinetochores for rapid generation of 'wait-anaphase' signal until every single KT pair achieves bi-orientation. This active SAC ('on-state') inhibits the anaphase-promoting complex/cyclosome (APC/C) activator Cdc20 (cell-division-cycle 20). Note that Ska binds to the Hec1 loop and its phosphorylation by Aurora B kinase subsequently abrogates its interaction with the KMN network. (3) Upon appropriate error-free kMT end-on attachments, Aurora B activates Plk1 that induces PP2A binding to BUBR1 causing the dephosphorylation of the RVSF/SILK motifs, thereby allowing PP1 to bind and act on Knl1. The binding of PP1 dephosphorylates the MELT repeats and the SAC components are released from the KMN network, extinguishing the SAC to an 'off' state. Microtubules and its associated proteins like MAPs and motor proteins are depicted. (4) After the SAC is satisfied and its components are removed from the kinetochore, APC/C regains its activity to degrade securin and cyclin B1 that triggers anaphase and exit from mitosis. Separase, a protease that cleaves the cohesins that hold sister chromatids together, is inhibited by binding to securin. But upon securin degradation, separase is released to cleave cohesin and allow the sister chromatids to undergo separation in anaphase.

mitotic process stand as an attractive therapeutic target in light of their central role in orchestrating faithful chromosome segregation. Advances in high-resolution imaging, proteomics and gene-silencing techniques have nurtured our understanding in this complex physiological process to a great extent. Since the research in our laboratory is directed toward unraveling the underlying biological and mechanistic nuances of kinetochoremicrotubule (kMT) attachment during mitosis, this review will comprehensively analyze and re-focus on a seemingly 
old yet completely untapped concept of possibility and potential of targeting the kMT attachments. The kMT attachments are known to be de-regulated in tumor cells and interfering with this process is speculated to drive massive chromosomal missegregation and tumor cell death (Janssen \& Medema 2013).

Kinetochores are mega-molecular multi-protein assemblies built upon centromeres and are involved in coupling the centromeric DNA to the plus ends of spindle microtubules. Some of the key components of the outer kinetochores are the protein complexes of the KMN (abbreviated for the Knl1 complex, the Mis12 complex and the Ndc80 complex) network that associates with KTs during prophase and disappears in telophase. The KMN network represents the major interface for kMT attachments (Cheeseman et al. 2006, DeLuca et al. 2006, Tooley \& Stukenberg 2011), and these attachments are regulated by mitotic kinase Aurora B (ABK) (Biggins \& Murray 2001, Tanaka et al. 2002). At the commencement of mitosis, kinetochores lacking spatial organization bind MTs indiscriminately leading to syntelic (sister KT pair attached to spindle arising from same pole) or merotelic (one KT is simultaneously attached to both the spindles emanating from opposite poles) attachments (Krenn $\&$ Musacchio 2015). At this point in early mitosis, it is imperative to keep the attachments labile and unstable so that the improperly attached MTs can be released and corrected. ABK imparts fidelity to this process by phosphorylating several kinetochore proteins including the members of the KMN network and thus weakens such erroneous kMT configurations (Welburn et al. 2010). However, with the progression of mitosis, stable attachments are a prerequisite to generate tension for chromosome movement. To accomplish this, there is a decline in the $\mathrm{ABK}$ activity and a concomitant increase in kinetochore phosphatase activity, which dephosphorylates the Ndc80 complex facilitating the formation of stable MT attachments (Liu et al. 2010). Therefore, a defective ABK regulatory system results in erroneous kMT attachments leading to chromosomal missegregation and chromosomal instability (CIN), a hallmark of cancer. In fact, cancer cells with CIN possess an inherently reduced capacity to correct erroneous kMT attachments and especially merotely (Bakhoum et al. 2009a,b, Bakhoum \& Compton 2012).

Highly expressed in cancer protein 1 (Hec1), a constituent of the evolutionary conserved Ndc80 complex of the KMN network directly bridges the KTs with MTs. As the name suggests, this protein is frequently overexpressed in cancer cells ( $\mathrm{Wu}$ et al. 2008). Consequently, Hec1 depletion in tumor cell lines and in xenografts induced mitotic abnormalities and cell death (Gurzov \& Izquierdo 2006, Li et al. 2007a). On the other hand, inducible expression of EGFP-Hec1 abolished the growth of HeLa cells in vitro and reduced substantial tumor growth in HeLa xenograft mouse model in vivo (Orticello et al. 2015). The EGFP-Hec1 expression led to excessive stabilization of kMT attachments, impaired chromosomal segregation and accumulation of multipolar spindles leading to catastrophic mitotic arrest with apoptosis, attenuation of cytokinesis and multinucleation as visualized by live cell imaging (Orticello et al. 2015). Implications of overexpression and silencing of Ndc80 in the tumorigenesis of pancreatic cancer has recently been illustrated (Meng et al. 2015). A recent study conducted high-throughput lethality RNAi screen of 6000 genes in a panel of ovarian cell lines and identified Hec1 as one of the four genes required for the survival of cancer cells (Sethi et al. 2012). Disruption of Ndc80 and Nuf2 complex formation using a small molecule inhibitor, INH1, has been shown to reduce the proliferation in breast cancer cells and reduce tumor growth in a xenograft mouse model (Wu et al. 2008). The siRNA-mediated knockdown of Ndc80 and Nuf2 has been shown to induce abnormal mitotic exit and apoptosis in colorectal cancer and gastric cancer cell lines (Kaneko et al. 2009).

Targeted knockdown of Knl1 (a constituent of KMN network), a member of the cancer/testis gene family that is predominantly expressed in the testis and widely expressed in primary tumors of different origins, induced apoptotic cell death in human cancer cell lines in vitro independent of the p53 status and markedly impeded the growth of implanted tumors in vivo (Urata et al. 2015). Recently, an interesting study demonstrated that the kinetochore genes are rarely overexpressed in isolation but instead their activation in cancer represents the coordinated and broad induction of core kinetochore module and the associated genes involved in cell cycle and DNA replication (Thiru et al. 2014).

Recent studies from our group have shown that Cdt1, a DNA replication licensing protein, is required for robust kMT attachments in human cells in addition to its established role in DNA replication origin licensing (Varma et al. 2012). Cdt1contributes to kMT attachment by binding to the conserved loop region of the Ndc80 complex, but the precise nature of how Cdt 1 and the loop domain function together is unknown. Perturbation of function of both the Ndc80 complex and Cdt1 interfere 
with the spindle assembly checkpoint, which is defective in cancer cells, and hence, promote them to divide uncontrollably (Diaz-Rodriguez et al. 2008, Varma et al. 2012). Overexpression of Cdt1 has been associated with many human cancers (Arentson et al. 2002, Bravou et al. 2005, Petropoulou et al. 2008). Specifically, Cdt1 has been found to be overexpressed in some cases of non-small-cell lung carcinomas and lymphoblastic lymphomas with an effect synergistic to the loss of p53 function (Karakaidos et al. 2004, Seo et al. 2005). With regard to endocrine-related cancers, the DNA replication licensing machinery including Cdt1 is emerging as an important therapeutic target to counter prostate cancer (D'Antonio et al. 2009, Majid et al. 2010, McCann et al. 2014, Wang et al. 2014). It is presumable that inhibition of replication licensing interferes with multiple pathways that influence cell proliferation including inhibition of DNA replication and cell cycle arrest, induction of DNA damage and genome instability and/or apoptosis, but it remains to be seen if Cdt1's role in cell division and chromosome segregation contributes to therapeutic potential in this case.

\section{Spindle assembly checkpoint (SAC)}

The spindle assembly checkpoint (SAC), a core network of proteins (Mad1, Mad2, Bub1, BubR1, Bub3, Mps1) constitute a surveillance mechanism employed by the cells to monitor the bipolar end-on attachment of each kinetochore to the MT before the transition into anaphase can ensue. Accumulation of these SAC components at the unattached kinetochores serves as a 'wait-signal' to delay the chromosome segregation until proper bi-orientation is established for all the kinetochore pairs. Thus, according to the kMT stabilostat model proposed by Bakhoum \& Compton, hypostable kMT attachments fail to adequately satisfy the SAC leading to mitotic delay/arrest, while hyperstable attachments cannot undergo appropriate error correction and persist to carry the attachment errors into anaphase leading to chromosomal missegregation and CIN (Bakhoum \& Compton 2012). Loss of SAC function has been attributed to CIN and aneuploidy in several cancers (Kops et al. 2005, Herman et al. 2015). Interestingly, few SAC proteins also have a direct role in kMT attachments independent of their checkpoint functions. BubR1 recruits PP2A phosphatase to the KT to counteract ABK activity, thereby dephosphorylating ABK substrates and promoting stable kMT attachments (Herman et al. 2015). Similarly, Bub1 has been implicated in phosphorylation of histone $\mathrm{H} 2 \mathrm{~A}$ resulting in localization of $\mathrm{ABK}$ at the centromeres (Herman et al. 2015). It is thus evident that there is a cross-talk and a close integration between kMT attachment and SAC. Defects in SAC-independent functions of SAC components may also be responsible for tumor formation (Ricke et al. 2008). In functional RNAi screens performed on patient-derived glioblastoma multiforme (GBM, a grade IV astrocytoma, an aggressive and common form of brain cancer in adults) stem-like cells (GSCs), many genes were specifically knocked down and some were found to ameliorate GSC expansion. Two of those identified genes were kinetochore-associated SAC proteins, BubR1 and BuGZ implicated in regulating kMT attachments (Herman et al. 2015).

Moreover, Bub1 binding to KT is achieved by Mps1 kinase-mediated phosphorylation of MELT repeats on Knl1, a protein within the KMN network. Mps1 levels were upregulated in a variety of tumors of different origins including bladder, anaplastic thyroid, breast, lung, esophagus and prostate (Colombo et al. 2010). A study using a low-molecular-weight inhibitor of Mps1 showed that the inhibitor could decrease the proliferation and viability of both tumor and non-cancer cells but induces apoptosis via poly (ADP-ribose) polymerase (PARP) cleavage specifically in the malignant cells (Kwiatkowski et al. 2010). Therefore, even though the specificity and effectiveness of using small-molecule inhibitors against the kinases like Mps1 and Bub1 in terms of targeting only tumor cells and sparing healthy cells warrants further investigation, Mps1 inhibitors have been promising in preclinical trials with some entering into the phase I clinical trials (Dorer et al. 2005, Hewitt et al. 2010, Santaguida et al. 2010, Tardif et al. 2011). Similarly, cycloalkenepyrazole inhibitors of Bub1 kinase activity have been patented but no evidence of efficacy has been presented till date (Tannous et al. 2013, Slee et al. 2014).

Several human tumor cells have been shown to harbor mutations in mitotic SAC genes encoding Bub1, BubR1, Mad1, Mad2 and in all the three members of Zw10-Rod-Zwilch complex (Kops et al. 2005). In prostate and pancreatic cancers, amino acids for Mad1 (R59C, R556C, R359Q and frameshift generating a stop codon at amino acid 318) and Bub1 (Y259C, H265N) are disrupted, respectively (Kops et al. 2005). Besides mutations in the SAC proteins, severe repression of Mad2 or BubR1 has been shown to result in massive chromosomal missegregation and apoptosis (Kops et al. 2004, Kienitz et al. 2005, Janssen \& Medema 2013). Prolonged activation of SAC (by generating unattached KTs) or paradoxically opposite 
mechanism of inhibiting the SAC (by reducing the levels of Mad2 or BubR1) both have been effective in causing lethality of cancer cells (Kops et al. 2004).

\section{Microtubule associated proteins (MAPs)}

The intracellular dynamic behavior of MTs is regulated by a concerted balance of MT-stabilizing (MAPs and $\mathrm{Tau}$ ) and de-stabilizing (stathmin family) proteins, all of them harbor tubulin-binding domain(s) (Bhat \& Setaluri 2007). Tau, an extensively investigated MAP is shown to be variably expressed in breast cancer cells and consistent with its MT-stabilizing function, loss of Tau expression was shown to sensitize breast cancer cells to the effect of paclitaxel (Smoter et al. 2011). MAP2 (found mainly in neurons) expression is associated with MT stabilization in metastatic melanoma cells leading to cell cycle arrest in G2-M and growth inhibition both in vivo and vitro (Fang et al. 2001). Besides this, expression of MAP2 has been associated with increased sensitivity to MTAs in docetaxel-sensitive pancreatic ductal adenocarcinoma (Veitia et al. 2000). Phosphorylated MAP4, a ubiquitously expressed MAP, has been correlated with a decrease in taxol sensitivity in ovarian cancer cells lines (Poruchynsky et al. 2001). On the contrary, non-phosphorylated forms of MAP4 are increased in vinblastine-resistant human leukemia cells indicating that the effects of these proteins are cell-type dependent and are more complex than anticipated. High levels of stathmin are reported in a variety of human malignancies (Mistry \& Atweh 2002, Mistry et al. 2005). Targeting stathmin using antisense in K562 leukemia cell line resulted in abrogation of malignant phenotype (Jeha et al. 1996). Similarly, adenovirus-mediated delivery of antistathmin ribozymes in prostate cancer cells resulted in massive dose-dependent inhibition of proliferation, accumulation of cells in G2-M and apoptosis (Mistry et al. 2005). Altered levels of stathmin and its regulatory pathways are also shown to be responsible for resistance of ovarian cancers to MT-targeting drugs such as paclitaxel (Balachandran et al. 2003).

Spindle and kinetochore-associated complex subunit 1 (Ska1) is a microtubule-binding protein at the outer kinetochore that is essential for proper chromosome segregation (Hanisch et al. 2006, Schmidt et al. 2012). A recent report demonstrates that Ska1 is important in the proliferation of oral adenosquamous carcinoma cells (Zhang et al. 2013a). Another group showed that overexpression of Ska accelerates cell division in human breast cells (Wright \& Brooks 2013). Li and coworkers used immunohistochemistry and quantitative RT-PCR to demonstrate Ska1 overexpression in human prostatic intraepithelial neoplasia (Li et al. 2014). Their studies also showed that the prostate-specific upregulation of Ska1 in a transgenic mouse model resulted in spontaneous tumorigenesis. Along the same lines, another study revealed that Ska1 expression was significantly higher in papillary thyroid carcinoma (PTC), which accounts for 79-94\% of thyroid cancers (Dong et al. 2015). Ska2 is also shown to be highly expressed in several cancer cell lines and clinical samples including small-cell lung and breast cancer (Rice et al. 2008). Thus, Ska silencing by RNAi might be a potential therapy for these cancer cells. The successful use of small-interfering RNA (RNAi) technology to silence critical gene products has generated significant anti-proliferative and/or pro-apoptotic effects in cellculture systems or in preclinical animal models (Pai et al. 2006, Akar et al. 2008, Qin et al. 2013, Zhang et al. 2013b). Long-lasting RNAi-based gene silencing can also be achieved using lentivirus-based expression systems (Park 2007). Nonetheless, significant obstacles such as in vivo delivery, partial suppression of target genes, nonspecific immune responses and off-target effects, need to be circumvented before this technology can pave its way to the clinics.

An extremely interesting and novel hypothesis proposed by Tang and Toda is that overexpression of Ndc80 would sequester and unfavorably absorb its accomplices like the Ska complex, Cdt1, the Dam1 complex, TACC-TOG (transforming acidic coiled coil, tumor overexpressed gene), which bind to Ndc80 internal loop region, thereby altering the dynamic flux/ equilibrium of these important kinetochore- or spindleassociated proteins in cells (Tang \& Toda 2015). Indeed, they demonstrated that overproduction of Ndc80 led to sequestration of its interacting partner, Dis1 in fission yeast, leading to the disruption of the MT structure. Albeit the study did not examine the localization of other loop-interacting proteins, it strongly presents a proof of concept that to compensate for the loss of function of these proteins in response to $\mathrm{Ndc} 80$ overexpression, their expression levels can be upregulated. In fact, several cancers report upregulation of Ndc80-loop-interacting proteins like Ska (Sun et al. 2014), TACC (Still et al. 1999), ch-TOG (colonic and hepatic tumor overexpressed gene) (Charrasse et al. 1995), kinesin 8 (Zhang et al. 2010) and Cdt1 (Arentson et al. 2002, Bravou et al. 2005, Petropoulou et al. 2008). 
Since in each cancer type, there exists a high variability and complexity in the expression of MAP-repertoire that either enhances or reduces tumor sensitivity to MTAs; it is imperative to generate a landscape of tumorspecific MAPs along with its regulatory components for a particular type of cancer. In the wake of advancement in proteome analysis, gene profiling/microarrays, mass spectroscopy and screening small-molecule libraries, this strategy should be deemed suitable to develop efficacious combinatorial therapies (adjunct with MTAs) to alter the expression of a relevant MAP in desired direction or to modulate MAP-tubulin interaction. Targeting the proteins/kinases that regulate the association of MAPs to MTs is another open area of research for the development of future cancer therapeutics.

\section{Mitotic kinases}

The process of mitosis utilizes phosphorylation as one of the major regulatory events for centrosome maturation, recruitment of checkpoint and kinetochore-associated proteins, spindle assembly and chromosomal segregation (Malumbres 2011). Therefore, any abnormality in choreography of these highly coordinated events is catastrophic, leading to tumorigenesis. Molecules/ inhibitors that target mitosis-specific kinases and phosphatases are proposed to improve the therapeutic index when used alone or with existing drug regimens by impacting slowly-dividing healthy cells to a remarkably lesser extent than the rapidly proliferating cancer cells. Advances in the field of crystallography, structurebased drug designing and chemical genetics can provide powerful platform for such invigorating discoveries. Moreover, dysregulation of mitotic kinases has been associated with uncontrolled and abnormal cell cycle progression; therefore, they can also serve as important diagnostic tools.

The most prominent and exhaustively characterized mitotic kinase is Cdk1 (Cyclin-dependent kinase 1). Based on the cell cycle stage, Cdk1 interacts with its binding partner, Cyclin A (controls entry and progression through G1) or Cyclin B1 (regulates G2-M transition). Cdk1/ Cyclin B initiates phosphorylation of its targets allowing entry into mitosis. Degradation of Cyclin B marks the exit from mitosis. Although, mutations or de-regulation of Cdk1 has not been reported in cancer, inhibition of Cdk1 has been shown to induce cell cycle arrest and apoptosis in breast cancer and gastric carcinoma (Lin et al. 2006, Li et al. 2007b, Schmit \& Ahmad 2007, Choi \& Kim 2008). An interphase Cdk, Cdk5 has been shown to be responsible for controlling cell motility and metastasis in prostate cancer (Strock et al. 2006). Many small-molecule pharmacological inhibitors targeting Cdks are in in different phases of clinical trials with moderate success stories (Asghar et al. 2015).

Besides Cdks, Aurora kinase A and B constitute major mitotic kinases. Aurora-A kinase (AAK) is implicated in centrosome separation and spindle formation at the onset of mitosis (Malumbres 2011). RNAi-mediated inhibition of AAK led to a delay in mitotic entry in human cells and conversely, overexpression of AAK led to mitotic irregularities, inhibition of cytokinesis and aneuploidy (Keen \& Taylor 2004). AAK overexpression is found in many cancer cell lines like breast, cervical, colorectal, gastric, ovarian, pancreatic and prostate (Sen et al. 1997, Carmena \& Earnshaw 2003). As discussed in the previous section, ABK contributes to generation of error-free KMT attachments. Similar to AAK, heightened expression of $\mathrm{ABK}$ is also associated with colorectal, prostate and thyroid carcinomas (Tatsuka et al. 1998, Sorrentino et al. 2005, Chieffi et al. 2006). Keen and Taylor systematically analyzed the expression levels of aurora- $A$, aurora- $B$ and aurora- $C$ mRNA in multiple primary tumor samples of different cancers (including breast, lung, colon, prostate, pancreas, liver, skin, stomach, rectum, esophagus, endometrium, cervix, bladder, ovary and thyroid) from diverse stages and origins using microarray analysis (Keen \& Taylor 2004). The results demonstrated that both Aurora-A/B were significantly overexpressed in tandem but Aurora-C was neither overexpressed nor correlated with Aurora-A or B expression. The use of small-molecule inhibitors targeting Aurora kinases for cancer therapeutics has been diligently summarized elsewhere (Keen \& Taylor 2004, Carvajal et al. 2006, Schmidt \& Bastians 2007, Lapenna \& Giordano 2009, Katayama \& Sen 2010).

Another important kinase is polo-like kinase 1 (Plk1), the levels of which are detected during G2-M transition and peaks during mitosis (Malumbres 2011). Plk1 is localized at centrosomes in prophase, and then enriches at the KTs and remains there throughout pro- and metaphase (Lu \& Yu 2009). Elevated level of Plk1 has been reported in a plethora of cancers including breast, gastric, endometrial, colorectal, ovarian, thyroid, pancreatic and prostate (Lu \& Yu 2009). Concomitantly, knockdown of Plk1 using antisense oligonucleotides or RNAi showed reduced cellular proliferation and a corresponding increase in cell death in many cancer cell lines including prostate cancer (Spankuch-Schmitt et al. 2002a,b, Nogawa et al. 2005, Reagan-Shaw \& Ahmad 2005). Plk1 has also been shown to phosphorylate BubR1 at multiple sites, which

Published by Bioscientifica Ltd 
is required for stable kMT attachment and chromosome alignment (Elowe et al. 2007). DAB2IP (disabled homolog 2-interacting protein) directly interacts with Plk1 and facilitates the mitotic activation of Plk1. Depletion of DAB2IP in PCa prostate cancer cells significantly reduced mitotic BubR1 phosphorylation, attenuated BubR1 recruitment to the KTs during prometaphase, compromised SAC activity and aberrant chromosomal segregation (Yu et al. 2016). However, it is noteworthy that other members of the Plk family, Plk2 and Plk4 function as tumor suppressors and thus the use of a Plk1 inhibitor that does not possess precise specificity would be alarming (Sudakin \& Yen 2007).

\section{Motor proteins in mitosis}

The outer peripheral region of an unattached kinetochore is a hub for motor proteins like CENP-E kinesin, cytoplasmic dynein-dynactin complex and other SAC proteins (Varma \& Salmon 2012). Kinesins are MT-based motor proteins that participate in a myriad of cellular functions like transport of vesicles, organelles, chromosomes and protein complexes and MT movement. All kinesins identified till date are characterized by a $\sim 340$ amino acid long motor domain called as 'head' harboring an ATP-binding pocket and a MT-binding interface. The kinesins containing the motor domain at the N-terminus typically move toward the actively growing plus-end of MTs, while the ones with the motor domain at the C-terminus possess minus-end directed motility. The ones with a central motor domain utilize ATP for MT depolymerization (Cross \& McAinsh 2014, Vicente \& Wordeman 2015). So far, 45 kif genes have been identified in mammals, which are divided into 14 broad families based on their structure (Chandrasekaran et al. 2015). One of the most important mitotic kinesins is the Kif11 (also known as Eg5 or kinesin spindle protein, KSP), a kinesin-5 family member involved in bipolar spindle formation in humans (Blangy et al. 1995). Kif15 (a Kinesin-12 family member) has been shown to functionally overlap with Kif11 in the separation of the centrosomes and in the formation of a bipolar spindle (Tanenbaum et al. 2009). The outward force created by Kif11 and Kif15 is counteracted by KifC1 (a Kinesin-14 motor), a minus-end directed motor, to help maintain the spindle length (Mountain et al. 1999). Several kinesin families contribute to the capture and congression of the chromosomes: kinesin-4 (Kif4), kinesin-7 (Kif10), kinesin-8 (Kif18A), kinesin-10 (Kif22), kinesin-13 (Kif2B, Kif2C) and kinesin-14 (KifC1). The molecular motors like dynein and Kif10 (also known as CENP-E, a kinesin-7 member) are key players in converting the 'lateral connection', wherein the kinetochores first contact the microtubule at the lattice rather than at the microtubule tip, into an 'end-on connection' at the plus-end tip of the microtubule to establish robust kMT attachments (Schaar et al. 1997, Wood et al. 1997, Kapoor et al. 2006, Cai et al. 2009). CENP-E has also been alluded in integrating kMT attachments and SAC by virtue of its ability to directly bind and modulate the function of BubR1 (Yao et al. 2000, Mao et al. 2003).

Very early studies in Drosophila and Xenopus had demonstrated that the inactivation of respective Kif11 homologs, KLP61F and Eg5 led to mitotic arrest with the accumulation of monoastral spindle (Sawin et al. 1992, Heck et al. 1993). Moreover, selective inhibition of Eg5 by antibody microinjection into human cells resulted in similar phenotype and mitotic arrest (Blangy et al. 1995). The fact that little or no $\operatorname{Eg} 5$ is detected in adult non-dividing cells but its expression is prominent in proliferating tissues during development, makes it vulnerable to be exploited as an alluring target (Castillo \& Justice 2007). Additionally, overexpression of Eg5 has been found in a variety of solid tumors and leukemias (Salmela \& Kallio 2013). Almost a decade ago, identification of monastrol, a small-molecule reversible allosteric inhibitor of the kinesin-5 motor protein/Eg5 aroused interest in using these novel lines of inhibitors to target a protein other than tubulin thereby avoiding the toxicity that encumbers the commonly used MTAs. The success of Eg5 inhibitors has been established in a broad range of tumor cell lines both in vivo and in vitro (DeBonis et al. 2004, Salmela \& Kallio 2013). A large number of Eg5 inhibitors, their mechanism of action and their efficacy in clinical trials or challenges has been discussed (Huszar et al. 2009).

Following the suite is CENP-E, which is also found to be expressed in elevated levels in several tumors (Wood et al. 2008), and thus, its inhibitors like GSK923295A have been developed that induced mitotic delay, apoptosis and tumor regression (Wood et al. 2010, Chung et al. 2012). Another category of drugs like Lonafarnib blocks farnesylation of CENP-E, depleting this protein from metaphase resulting in defective kMT attachments, reduction in tension between sister kinetochores and activation of SAC (Schafer-Hales et al. 2007). Lonafarnib either alone or in combination with other drugs has also proven successful (Ashar et al. 2000, Schafer-Hales et al. 2007, Penna et al. 2017).
() 2017 Society for Endocrinology Printed in Great Britain
Published by Bioscientifica Ltd 
Although Eg5 and CENP-E are the two most popularly targeted kinesins, it is exciting to note that the other kinesins are still open for the development of cancer therapeutics. Kif14, a kinesin 3 family member, is overexpressed in ovarian, pancreatic, laryngeal, breast, lung and retinoblastoma tumors and HeLa cells deficient in Kif14 failed to undergo cytokinesis generating binucleate cells that apoptosized after subsequent rounds of impaired mitosis (Carleton et al. 2006, Abiatari et al. 2009, Theriault et al. 2012). An RNAi-based screen of 41 human kinesins identified at least 8 motor proteins in addition to Eg5, CENP-E and Kif14, which when knocked down impacted mitosis and subsequent cytokinesis (Zhu et al. 2005). Many reviews expansively document the various studies that highlight the amplification of various kinesin genes in cancer (Yu \& Feng 2010, Rath \& Kozielski 2012, Chandrasekaran et al. 2015). MCAK, a Kinesin-13, family member involved in MT depolymerization, has been shown to be upregulated in a genome-wide expression screen of 81 breast tissues (Nishidate et al. 2004). Intriguingly, MCAK expression not only has a relationship with progression of malignancy but also with taxane resistance. Depletion of MCAK has been found to increase the sensitivity of paclitaxel-resistant cells to paclitaxel (Ganguly et al. 2011).

Although the plus-end-directed MT motor proteins have been actively studied and targeted for the development of anti-cancer therapeutics, the minus-enddirected motor protein dynein has not received similar attention. Dynein's function in inactivating the SAC has been widely recognized (Wojcik et al. 2001, Vallee et al. 2006) but how its regulation can contribute to cancer progression remains obscure. Dr Mulder's laboratory previously had shown that km23-1, a light chain of dynein (also called DYNLRB1/LC7-1/robl-1/DNLC2A/DYRB1) is defective in 50\% of ovarian cancers (Tang et al. 2002). Their recent work demonstrated that overexpression of km23-1 in highly aggressive SKOV-3 human ovarian carcinoma cells (HOCCs) inhibited both monolayer proliferation and anchorage-independent growth of the cells causing an arrest in prometaphase/metaphase and also halted the tumorigenicity of the HOCCs in a xenograft model (Pulipati et al. 2011).

\section{Other not 'so popular' yet druggable mitotic protein targets}

Since mitosis is an extremely tightly controlled process while tumor cells have limited mechanisms to evade the targeted pharmacological drugs, the pursuit for identifying other druggable targets is worthwhile. Usually mitotic inhibitors rely on the induction of apoptosis by prolonged mitotic arrest attained via activation of the SAC resulting from aberrant spindle dynamics (Manchado et al. 2012). However, even in the presence of active SAC, sometimes, residual APC/C activity is observed, and this phenomenon is coined as 'mitotic slippage' (Brito \& Rieder 2006). APC/C-Cdc20, the anaphase-promoting complex, is an E3 ubiquitin ligase that triggers mitotic exit by targeting Cyclin B for degradation, thus inhibiting Cdk1 activity. Mitotic slippage occurs via stochastic Cyclin B degradation even in the presence of an active checkpoint (Brito \& Rieder 2006). Since the present day anti-mitotic strategies depend on SAC activation, their effectiveness is dramatically hampered by mitotic slippage, a process that occurs at high rate in cancer cells (Manchado et al. 2012). Consequently, it is beneficial to target factors downstream of the checkpoint that do not depend on functional SAC to circumvent slippage issues. Targeting APC/C function might therefore serve as a promising approach as its inhibition would prevent background Cyclin B proteolysis and consequently enhance mitotic arrest while averting mitotic slippage. Moreover, deregulated expression and mutations in APC/C subunits or its co-activators (Cdc20 and Cdh1) have been linked with tumorigenesis (Smolders \& Teodoro 2011). Accordingly, depletion of Cdc20 was able to elicit metaphase arrest in cell lines and killing of tumor cells in a mouse model (Huang et al. 2009, Manchado et al. 2010). TAME, a prodrug that reduced the APC-Cdc20 interaction, has been found to be effective in tumor cells (Zeng et al. 2010). Thus, inhibiting mitotic exit by targeting APC/C complex provokes a permanent metaphase arrest by preventing Cyclin B1 degradation, thus irreversibly leading to cell death; bolstering the validity of this approach of targeting mitotic exit.

Constitutive centromere-associated network (CCAN) is a complex of at least $\sim 16$ proteins that serves as a bridge between CENP-A in active inner centromeric chromatin and the outer kinetochore proteins including the KMN network that binds to MTs (McAinsh \& Meraldi 2011). Recently, a study was conducted wherein the gene expression from 12 different types of human cancers, including breast, lung, liver and prostate was analyzed and the CENP genes were found to be deregulated (Zhang et al. 2016). Overexpression of CENP-K in ovarian cancer was found to correlate with poor patient survival and predictive prognosis (Lee et al. 2015). Enhanced levels of CENP-A was also identified in several human 
malignancies, including hepatocellular carcinoma (Li et al. 2011), colorectal cancer (Tomonaga et al. 2003), lung adenocarcinoma (Wu et al. 2012), poor prognostic impact in estrogen receptor-positive breast cancer (McGovern et al. 2012) and epithelial ovarian cancer (Qiu et al. 2013). Moreover, CENP-E/F/H/J/T has significant positive hits in the Catalogue of Somatic Mutations in Cancer (COSMIC) database for cancerassociated mutations (Bamford et al. 2004). However, a direct correlation between the expression levels of these CENP proteins and cancer remains largely obscure. These studies unequivocally indicate that these centromeric proteins even if currently are not targeted for therapeutics can at least participate as diagnostic biomarkers for tumors.

Condensins are a group of proteins that are required for proper chromosome assembly, condensation and segregation during mitosis (Ono et al. 2004). A study has revealed that the changes in nuclear shape observed after Condensin II depletion is a unique property of transformed cells and hence represents an attractive target for cancer cells specifically (George et al. 2014).

Protein acetylation on lysine residues is a key posttranslational modification that influences several cellular processes (Yang \& Seto 2008). This dynamic and reversible modification is mediated by a concerted action of histone acetyltransferases (HATs) and histone deacetylases (HDACs). HDACs play a role in epigenetic modification of chromatin structure in response to environmental changes and are found to be elevated in various human cancers (Marks 2010). One of the HDACs, HDAC3, was shown to be localized on the mitotic spindle and its knockdown resulted in impaired kMT attachments, collapsed spindle surrounded by a dome-like configuration of chromosomes and subsequent activation of SAC in HDAC3-depleted cells (Ishii et al. 2008). Fairly recently, a study demonstrated that Aurora B kinase is present in an acetylated form in PC3 prostate cancer cells. Since Aurora B kinase is more active in deacetylated state, inhibition of HDAC3, a substrate for this kinase, resulted in reduced kinase activity and significant defects in Aurora B-dependent mitotic processes, including kMT attachment and chromosome congression (Fadri-Moskwik et al. 2012). HDAC inhibitors are recognized as anti-proliferative agents and are thus attractive candidates for anti-cancer therapeutic intervention (Eot-Houllier et al. 2009). These drugs arrest the cell cycle at $G_{1}$ and $G_{2} / M$ phase and induce apoptosis, but their precise mechanism of action still remains elusive (Bolden et al. 2006).
Advancement in genome-scale loss-of-function screens using RNAi led to the identification of a panorama of essential proteins involved in cell cycle regulation and progression (Mukherji et al. 2006). However, most of these are yet to be tested for their potential in arresting tumor growth. One such protein identified in this screen is Haspin, a kinase that is essential for maintaining cohesion between the sister chromatids (Dai \& Higgins 2005). The inhibition of this kinase resulted in SAC activation and mitotic arrest reinforcing it as a future plausible cancer target (Petretti et al. 2006).

\section{Future challenges on the road from bench to bedside}

Despite the convincing preclinical results yielded by newgeneration anti-mitotic agents, their clinical efficacy has been promiscuous compared to the microtubule targeting poisons (Manchado et al. 2012, Mc Gee 2015). One of the several reasons that afflict development of antimitotic therapeutics emanate from the fact that the cells in culture or xenograft animal models have considerably shorter doubling time compared to the actual tumors in the patients (Komlodi-Pasztor et al. 2012, Mitchison 2012). This indicates that at a particular time, only a small fraction of tumor cells are undergoing mitosis thus leaving the dormant tumor cells (which are in G1- or S-phase) completely indifferent or refractory to the drugs that target cell proliferation or aimed at proteins whose expression is highly restricted to only one phase of the cell cycle (like mitotic proteins). This observation also underscores the necessity for frequent drug administration to avoid the likelihood of repopulation of the tumor cells upon clearance of the drug from the system. In addition to the low mitotic index observed in human tumors (estimated to be $<1 \%$ ), the proliferation rate extensively varies in different patients, origins and locations of the tumor (Amadori et al. 1997). Furthermore, although these approaches target proteins that are upregulated in cancer cells, thereby providing a narrow/steep therapeutic window to preferentially kill the cancer cells, they still suffer from non-specificity and are thus accompanied by side effects. Another issue underlying the inadequacy of anti-mitotic drugs has been outlined by Mitchison as 'poor drug retention' (Mitchison 2012). For instance, while paclitaxel is retained in the tumor cells for a week and can exert its cytotoxicity for a longer duration, the newer mitosis-selective inhibitors have a median half-life of only $\sim 13 \mathrm{~h}$ (Chung et al. 2012). Drug resistance has also

Published by Bioscientifica Ltd. 
been reported for the newer mitosis-selective agents like the Eg5 inhibitor (Tcherniuk et al. 2010). There are several ways envisaged to evade these issues: (i) Identifying cancer-specific targets that have oncogenic role outside of mitosis (i.e., important throughout the cell cycle). One such rare candidate is survivin whose expression is cell cycle regulated that escalates to a maximum level during the $\mathrm{G} 2 / \mathrm{M}$ phase, consistent with its role in mitosis. Moreover, survivin is overexpressed in practically every human tumor examined (Chan et al. 2012). Attenuation of survivin culminated in caspase-dependent apoptosis both in vitro and in vivo (Chan et al. 2010). Downregulation of survivin resulted in severe defects in spindle assembly, compromised SAC, aberrant chromosome motility and incomplete cytokinesis leading to ploidy (Li et al. 1999). Thus, targeting survivin is anticipated to transcend the failings of present day anti-mitotics. Indeed, an early-phase trial of survivin inhibitors on humans showed tolerable toxicity and encouraging clinical efficacy (Church \& Talbot 2012). Another such molecule is Cdt1 that has been identified very recently to have a mitotic role (specifically in maintaining robust kMT attachments via its interaction with the Hec1 loop) independent of its prototypic role in DNA replication during the G1 phase (Rialland et al. 2002, Varma et al. 2012). Using high-resolution microscopy, antibody microinjection experiments and biochemistry, it was shown that Cdt1, which gets degraded post S-phase, re-accumulates in G2-M and its inhibition led to a mitotic arrest (Varma et al. 2012). Therefore, targeting Cdt1 seems to be an extremely optimistic approach for targeting both types of cancer cells that are undergoing mitosis and also those which are dormant in the G1 phase. Moreover, cancer cells that make aberrant amounts of Cdt1 are expected to experience problems in both replication and mitosis and thus artificially ramping up Cdt1 in such cells is envisioned to push them through an apoptotic pathway. Our laboratory is currently focusing to delineate the precise role of Cdt1 in mitosis, (ii) Mc Gee eloquently proposes that if we re-focus our attention on understanding the post-mitotic signals that integrate with the cell death and senescence pathways, we will discover novel strategies to drive cells down into a precisely defined anti-proliferative route, which is likely to recapitulate and synergize with the current success of anti-mitotic drugs to kill cancer cells before they adapt or develop drug resistance (Mc Gee 2015).

Considering cell cycle deregulation, unscheduled proliferation, genomic instability and chromosomal instability as few of the common features of almost every type of tumor cells, the recent accelerated progress in the identification and characterization of new cell cyclespecific druggable biomarkers/mechanisms accompanied by concomitant pharmacological advances that will enable us to design and target these wonder drugs better, their lies ahead an exciting era for the development of an effective cancer therapy in the near future.

Declaration of interest

The authors declare that there is no conflict of interest that could be perceived as prejudicing the impartiality of this review.

\section{Funding}

The funding from the National Cancer Institute (R00CA178188) to D V is acknowledged.

\section{References}

Abiatari I, DeOliveira T, Kerkadze V, Schwager C, Esposito I, Giese NA, Huber P, Bergman F, Abdollahi A, Friess H, et al. 2009 Consensus transcriptome signature of perineural invasion in pancreatic carcinoma. Molecular Cancer Therapeutics 8 1494-1504. (doi:10.1158/1535-7163.MCT-08-0755)

Akar U, Chaves-Reyez A, Barria M, Tari A, Sanguino A, Kondo Y, Kondo S, Arun B, Lopez-Berestein G \& Ozpolat B 2008 Silencing of Bcl-2 expression by small interfering RNA induces autophagic cell death in MCF-7 breast cancer cells. Autophagy 4 669-679. (doi:10.4161/auto.6083)

Akhmanova A \& Steinmetz MO 2015 Control of microtubule organization and dynamics: two ends in the limelight. Nature Reviews Molecular Cell Biology 16 711-726. (doi:10.1038/nrm4084)

Alushin GM, Lander GC, Kellogg EH, Zhang R, Baker D \& Nogales E 2014 High-resolution microtubule structures reveal the structural transitions in alphabeta-tubulin upon GTP hydrolysis. Cell $\mathbf{1 5 7}$ 1117-1129. (doi:10.1016/j.cell.2014.03.053)

Amadori D, Volpi A, Maltoni R, Nanni O, Amaducci L, Amadori A, Giunchi DC, Vio A, Saragoni A \& Silvestrini R 1997 Cell proliferation as a predictor of response to chemotherapy in metastatic breast cancer: a prospective study. Breast Cancer Research and Treatment 43 7-14. (doi:10.1023/A:1005780107879)

Arentson E, Faloon P, Seo J, Moon E, Studts JM, Fremont DH \& Choi K 2002 Oncogenic potential of the DNA replication licensing protein CDT1. Oncogene 21 1150-1158. (doi:10.1038/sj.onc.1205175)

Asghar U, Witkiewicz AK, Turner NC \& Knudsen ES 2015 The history and future of targeting cyclin-dependent kinases in cancer therapy. Nature Reviews Drug Discovery 14 130-146. (doi:10.1038/nrd4504)

Ashar HR, James L, Gray K, Carr D, Black S, Armstrong L, Bishop WR \& Kirschmeier P 2000 Farnesyl transferase inhibitors block the farnesylation of CENP-E and CENP-F and alter the association of CENP-E with the microtubules. Journal of Biological Chemistry 275 30451-30457. (doi:10.1074/jbc.M003469200)

Bakhoum SF \& Compton DA 2012 Chromosomal instability and cancer: a complex relationship with therapeutic potential. Journal of Clinical Investigation 122 1138-1143. (doi:10.1172/JCI59954)

Bakhoum SF, Genovese G \& Compton DA 2009a Deviant kinetochore microtubule dynamics underlie chromosomal instability. Current Biology 19 1937-1942. (doi:10.1016/j.cub.2009.09.055)
(C) 2017 Society for Endocrinology Printed in Great Britain
Published by Bioscientifica Ltd. 
Bakhoum SF, Thompson SL, Manning AL \& Compton DA 2009b Genome stability is ensured by temporal control of kinetochoremicrotubule dynamics. Nature Cell Biology 11 27-35. (doi:10.1038/ ncb1809)

Balachandran R, Welsh MJ \& Day BW 2003 Altered levels and regulation of stathmin in paclitaxel-resistant ovarian cancer cells. Oncogene 22 8924-8930. (doi:10.1038/sj.onc.1207060)

Bamford S, Dawson E, Forbes S, Clements J, Pettett R, Dogan A, Flanagan A, Teague J, Futreal PA, Stratton MR, et al. 2004 The COSMIC (Catalogue of Somatic Mutations in Cancer) database and website. British Journal of Cancer 91 355-358.

Bhat KM \& Setaluri V 2007 Microtubule-associated proteins as targets in cancer chemotherapy. Clinical Cancer Research 13 2849-2854. (doi:10.1158/1078-0432.CCR-06-3040)

Biggins S \& Murray AW 2001 The budding yeast protein kinase Ipl1/ Aurora allows the absence of tension to activate the spindle checkpoint. Genes and Development 15 3118-3129. (doi:10.1101/ gad.934801)

Blangy A, Lane HA, d'Herin P, Harper M, Kress M \& Nigg EA 1995 Phosphorylation by p34cdc2 regulates spindle association of human Eg5, a kinesin-related motor essential for bipolar spindle formation in vivo. Cell 83 1159-1169. (doi:10.1016/0092-8674(95)90142-6)

Boggs AE, Vitolo MI, Whipple RA, Charpentier MS, Goloubeva OG, Ioffe OB, Tuttle KC, Slovic J, Lu Y, Mills GB, et al. 2015 alpha-Tubulin acetylation elevated in metastatic and basal-like breast cancer cells promotes microtentacle formation, adhesion, and invasive migration. Cancer Research 75 203-215. (doi:10.1158/0008-5472. CAN-13-3563)

Bolden JE, Peart MJ \& Johnstone RW 2006 Anticancer activities of histone deacetylase inhibitors. Nature Reviews Drug Discovery $\mathbf{5}$ 769-784. (doi:10.1038/nrd2133)

Bravou V, Nishitani H, Song SY, Taraviras S \& Varakis J 2005 Expression of the licensing factors, Cdt1 and Geminin, in human colon cancer. International Journal of Oncology 27 1511-1518.

Brito DA \& Rieder CL 2006 Mitotic checkpoint slippage in humans occurs via cyclin B destruction in the presence of an active checkpoint. Current Biology 16 1194-1200. (doi:10.1016/j. cub.2006.04.043)

Cai S, O'Connell CB, Khodjakov A \& Walczak CE 2009 Chromosome congression in the absence of kinetochore fibres. Nature Cell Biology 11 832-838. (doi:10.1038/ncb1890)

Carleton M, Mao M, Biery M, Warrener P, Kim S, Buser C, Marshall CG, Fernandes C, Annis J \& Linsley PS 2006 RNA interference-mediated silencing of mitotic kinesin KIF14 disrupts cell cycle progression and induces cytokinesis failure. Molecular and Cellular Biology 26 3853-3863. (doi:10.1128/MCB.26.10.3853-3863.2006)

Carmena M \& Earnshaw WC 2003 The cellular geography of aurora kinases. Nature Reviews Molecular Cell Biology 4 842-854. (doi:10.1038/nrm1245)

Carvajal RD, Tse A \& Schwartz GK 2006 Aurora kinases: new targets for cancer therapy. Clinical Cancer Research 12 6869-6875. (doi:10.1158/1078-0432.CCR-06-1405)

Castillo A \& Justice MJ 2007 The kinesin related motor protein, Eg5, is essential for maintenance of pre-implantation embryogenesis. Biochemical and Biophysical Research Communications 357 694-699. (doi:10.1016/j.bbrc.2007.04.021)

Castro-Castro A, Janke C, Montagnac G, Paul-Gilloteaux P \& Chavrier P 2012 ATAT1/MEC-17 acetyltransferase and HDAC6 deacetylase control a balance of acetylation of alpha-tubulin and cortactin and regulate MT1-MMP trafficking and breast tumor cell invasion. European Journal of Cell Biology 91 950-960. (doi:10.1016/j. ejcb.2012.07.001)

Chan KS, Wong CH, Huang YF \& Li HY 2010 Survivin withdrawal by nuclear export failure as a physiological switch to commit cells to apoptosis. Cell Death and Disease 1 e57. (doi:10.1038/cddis.2010.34)
Chan KS, Koh CG \& Li HY 2012 Mitosis-targeted anti-cancer therapies: where they stand. Cell Death and Disease 3 e411. (doi:10.1038/ cddis.2012.148)

Chandrasekaran G, Tatrai P \& Gergely F 2015 Hitting the brakes: targeting microtubule motors in cancer. British Journal of Cancer $\mathbf{1 1 3}$ 693-698. (doi:10.1038/bjc.2015.264)

Charrasse S, Mazel M, Taviaux S, Berta P, Chow T \& Larroque C 1995 Characterization of the cDNA and pattern of expression of a new gene over-expressed in human hepatomas and colonic tumors. European Journal of Biochemistry 234 406-413. (doi:10.1111/j.1432-1033.1995.406_b.x)

Cheeseman IM, Chappie JS, Wilson-Kubalek EM \& Desai A 2006 The conserved KMN network constitutes the core microtubule-binding site of the kinetochore. Cell 127 983-997. (doi:10.1016/j. cell.2006.09.039)

Chieffi P, Cozzolino L, Kisslinger A, Libertini S, Staibano S, Mansueto G, De Rosa G, Villacci A, Vitale M, Linardopoulos S, et al. 2006 Aurora $\mathrm{B}$ expression directly correlates with prostate cancer malignancy and influence prostate cell proliferation. Prostate 66 326-333. (doi:10.1002/pros.20345)

Choi EJ \& Kim GH 2008 Daidzein causes cell cycle arrest at the G1 and G2/M phases in human breast cancer MCF-7 and MDA-MB-453 cells. Phytomedicine 15 683-690. (doi:10.1016/j.phymed.2008.04.006)

Chung V, Heath EI, Schelman WR, Johnson BM, Kirby LC, Lynch KM, Botbyl JD, Lampkin TA \& Holen KD 2012 First-time-in-human study of GSK923295, a novel antimitotic inhibitor of centromereassociated protein E (CENP-E), in patients with refractory cancer. Cancer Chemotherapy and Pharmacology 69 733-741. (doi:10.1007/ s00280-011-1756-z)

Church DN \& Talbot DC 2012 Survivin in solid tumors: rationale for development of inhibitors. Current Oncology Reports 14 120-128. (doi:10.1007/s11912-012-0215-2)

Cleveland DW \& Sullivan KF 1985 Molecular biology and genetics of tubulin. Annual Review of Biochemistry 54 331-365. (doi:10.1146/ annurev.bi.54.070185.001555)

Colombo R, Caldarelli M, Mennecozzi M, Giorgini ML, Sola F, Cappella P, Perrera C, Depaolini SR, Rusconi L, Cucchi U, et al. 2010 Targeting the mitotic checkpoint for cancer therapy with NMS-P715, an inhibitor of MPS1 kinase. Cancer Research 70 10255-10264. (doi:10.1158/0008-5472.CAN-10-2101)

Cross RA \& McAinsh A 2014 Prime movers: the mechanochemistry of mitotic kinesins. Nature Reviews Molecular Cell Biology 15 257-271. (doi:10.1038/nrm3768)

Curry EA 3rd, Murry DJ, Yoder C, Fife K, Armstrong V, Nakshatri H, O'Connell M \& Sweeney CJ 2004 Phase I dose escalation trial of feverfew with standardized doses of parthenolide in patients with cancer. Investigational New Drugs 22 299-305. (doi:10.1023/B:DRUG.0000026256.38560.be)

D'Antonio JM, Vander Griend DJ \& Isaacs JT 2009 DNA licensing as a novel androgen receptor mediated therapeutic target for prostate cancer. Endocrine-Related Cancer 16 325-332. (doi:10.1677/erc-08-0205)

Dai J \& Higgins JM 2005 Haspin: a mitotic histone kinase required for metaphase chromosome alignment. Cell Cycle 4 665-668. (doi:10.4161/cc.4.5.1683)

DeBonis S, Skoufias DA, Lebeau L, Lopez R, Robin G, Margolis RL, Wade RH \& Kozielski F 2004 In vitro screening for inhibitors of the human mitotic kinesin Eg5 with antimitotic and antitumor activities. Molecular Cancer Therapeutics 3 1079-1090.

DeLuca JG, Gall WE, Ciferri C, Cimini D, Musacchio A \& Salmon ED 2006 Kinetochore microtubule dynamics and attachment stability are regulated by Hec1. Cell 127 969-982. (doi:10.1016/j. cell.2006.09.047)

Desai A \& Mitchison TJ 1997 Microtubule polymerization dynamics. Annual Review of Cell and Developmental Biology 13 83-117. (doi:10.1146/annurev.cellbio.13.1.83)
๑ 2017 Society for Endocrinology Printed in Great Britain
Published by Bioscientifica Ltd. 
Diaz-Rodriguez E, Sotillo R, Schvartzman JM \& Benezra R 2008 Hec1 overexpression hyperactivates the mitotic checkpoint and induces tumor formation in vivo. PNAS 105 16719-16724. (doi:10.1073/ pnas.0803504105)

Dong C, Wang XL \& Ma BL 2015 Expression of spindle and kinetochore-associated protein 1 is associated with poor prognosis in papillary thyroid carcinoma. Disease Markers 2015616541.

Dorer RK, Zhong S, Tallarico JA, Wong WH, Mitchison TJ \& Murray AW 2005 A small-molecule inhibitor of Mps1 blocks the spindlecheckpoint response to a lack of tension on mitotic chromosomes. Current Biology 15 1070-1076. (doi:10.1016/j.cub.2005.05.020)

Dozier JH, Hiser L, Davis JA, Thomas NS, Tucci MA, Benghuzzi HA, Frankfurter A, Correia JJ \& Lobert S 2003 Beta class II tubulin predominates in normal and tumor breast tissues. Breast Cancer Research 5 R157-R169. (doi:10.1186/bcr631)

Elowe S, Hummer S, Uldschmid A, Li X \& Nigg EA 2007 Tensionsensitive Plk1 phosphorylation on BubR1 regulates the stability of kinetochore microtubule interactions. Genes and Development 21 2205-2219. (doi:10.1101/gad.436007)

Eot-Houllier G, Fulcrand G, Magnaghi-Jaulin L \& Jaulin C 2009 Histone deacetylase inhibitors and genomic instability. Cancer Letters 274 169-176. (doi:10.1016/j.canlet.2008.06.005)

Fadri-Moskwik M, Weiderhold KN, Deeraksa A, Chuang C, Pan J, Lin SH \& Yu-Lee LY 2012 Aurora B is regulated by acetylation/deacetylation during mitosis in prostate cancer cells. FASEB Journal 26 4057-4067. (doi:10.1096/fj.12-206656)

Fang D, Hallman J, Sangha N, Kute TE, Hammarback JA, White WL \& Setaluri V 2001 Expression of microtubule-associated protein 2 in benign and malignant melanocytes: implications for differentiation and progression of cutaneous melanoma. American Journal of Pathology 158 2107-2115. (doi:10.1016/S00029440(10)64682-2)

Fletcher DA \& Mullins RD 2010 Cell mechanics and the cytoskeleton. Nature 463 485-492. (doi:10.1038/nature08908)

Fonrose X, Ausseil F, Soleilhac E, Masson V, David B, Pouny I, Cintrat JC, Rousseau B, Barette C, Massiot G, et al. 2007 Parthenolide inhibits tubulin carboxypeptidase activity. Cancer Research 67 3371-3378. (doi:10.1158/0008-5472.CAN-06-3732)

Fujita M 2006 Cdt1 revisited: complex and tight regulation during the cell cycle and consequences of deregulation in mammalian cells. Cell Division 1 22. (doi:10.1186/1747-1028-1-22)

Ganguly A, Yang H \& Cabral F 2011 Overexpression of mitotic centromere-associated Kinesin stimulates microtubule detachment and confers resistance to paclitaxel. Molecular Cancer Therapeutics 10 929-937. (doi:10.1158/1535-7163.MCT-10-1109)

George CM, Bozler J, Nguyen HQ \& Bosco G 2014 Condensins are required for maintenance of nuclear architecture. Cells 3 865-882. (doi:10.3390/cells3030865)

Ghantous A, Sinjab A, Herceg Z \& Darwiche N 2013 Parthenolide: from plant shoots to cancer roots. Drug Discovery Today 18 894-905. (doi:10.1016/j.drudis.2013.05.005)

Gurzov EN \& Izquierdo M 2006 RNA interference against Hec1 inhibits tumor growth in vivo. Gene Therapy 13 1-7. (doi:10.1038/sj. gt.3302595)

Hanisch A, Sillje HH \& Nigg EA 2006 Timely anaphase onset requires a novel spindle and kinetochore complex comprising Ska1 and Ska2. EMBO Journal 25 5504-5515. (doi:10.1038/sj.emboj.7601426)

Hayden JH, Bowser SS \& Rieder CL 1990 Kinetochores capture astral microtubules during chromosome attachment to the mitotic spindle: direct visualization in live newt lung cells. Journal of Cell Biology $\mathbf{1 1 1}$ 1039-1045. (doi:10.1083/jcb.111.3.1039)

Heck MM, Pereira A, Pesavento P, Yannoni Y, Spradling AC \& Goldstein LS 1993 The kinesin-like protein KLP61F is essential for mitosis in Drosophila. Journal of Cell Biology 123 665-679. (doi:10.1083/ jcb.123.3.665)
Herman JA, Toledo CM, Olson JM, DeLuca JG \& Paddison PJ 2015 Molecular pathways: regulation and targeting of kinetochoremicrotubule attachment in cancer. Clinical Cancer Research 21 233-239. (doi:10.1158/1078-0432.CCR-13-0645)

Hewitt L, Tighe A, Santaguida S, White AM, Jones CD, Musacchio A, Green S \& Taylor SS 2010 Sustained Mps1 activity is required in mitosis to recruit O-Mad2 to the Mad1-C-Mad2 core complex. Journal of Cell Biology 190 25-34. (doi:10.1083/jcb.201002133)

Huang HC, Shi J, Orth JD \& Mitchison TJ 2009 Evidence that mitotic exit is a better cancer therapeutic target than spindle assembly. Cancer Cell 16 347-358. (doi:10.1016/j.ccr.2009.08.020)

Huszar D, Theoclitou ME, Skolnik J \& Herbst R 2009 Kinesin motor proteins as targets for cancer therapy. Cancer and Metastasis Reviews 28 197-208. (doi:10.1007/s10555-009-9185-8)

Ishii S, Kurasawa Y, Wong J \& Yu-Lee LY 2008 Histone deacetylase 3 localizes to the mitotic spindle and is required for kinetochoremicrotubule attachment. PNAS 105 4179-4184. (doi:10.1073/ pnas.0710140105)

Janke C \& Bulinski JC 2011 Post-translational regulation of the microtubule cytoskeleton: mechanisms and functions. Nature Reviews Molecular Cell Biology 12 773-786. (doi:10.1038/nrm3227)

Janssen A \& Medema RH 2013 Genetic instability: tipping the balance. Oncogene 32 4459-4470. (doi:10.1038/onc.2012.576)

Jeha S, Luo XN, Beran M, Kantarjian H \& Atweh GF 1996 Antisense RNA inhibition of phosphoprotein p18 expression abrogates the transformed phenotype of leukemic cells. Cancer Research 56 1445-1450.

Job D, Valiron O \& Oakley B 2003 Microtubule nucleation. Current Opinion in Cell Biology 15 111-117. (doi:10.1016/S09550674(02)00003-0)

Jordan MA 2002 Mechanism of action of antitumor drugs that interact with microtubules and tubulin. Current Medicinal Chemistry: AntiCancer Agents 2 1-17. (doi:10.2174/1568011023354290)

Jordan MA \& Wilson L 2004 Microtubules as a target for anticancer drugs. Nature Reviews Cancer 4 253-265. (doi:10.1038/nrc1317)

Kaneko N, Miura K, Gu Z, Karasawa H, Ohnuma S, Sasaki H, Tsukamoto N, Yokoyama S, Yamamura A, Nagase H, et al. 2009 siRNA-mediated knockdown against CDCA1 and KNTC2, both frequently overexpressed in colorectal and gastric cancers, suppresses cell proliferation and induces apoptosis. Biochemical and Biophysical Research Communications 390 1235-1240. (doi:10.1016/j.bbrc.2009.10.127)

Kapoor TM, Lampson MA, Hergert P, Cameron L, Cimini D, Salmon ED, McEwen BF \& Khodjakov A 2006 Chromosomes can congress to the metaphase plate before biorientation. Science 311 388-391. (doi:10.1126/science.1122142)

Karakaidos P, Taraviras S, Vassiliou LV, Zacharatos P, Kastrinakis NG, Kougiou D, Kouloukoussa M, Nishitani H, Papavassiliou AG, Lygerou $\mathrm{Z}$, et al. 2004 Overexpression of the replication licensing regulators hCdt1 and hCdc6 characterizes a subset of non-small-cell lung carcinomas: synergistic effect with mutant p53 on tumor growth and chromosomal instability - evidence of E2F-1 transcriptional control over hCdt1. American Journal of Pathology 165 1351-1365. (doi:10.1016/S0002-9440(10)63393-7)

Kashiwaya K, Nakagawa H, Hosokawa M, Mochizuki Y, Ueda K, Piao L, Chung S, Hamamoto R, Eguchi H, Ohigashi H, et al. 2010 Involvement of the tubulin tyrosine ligase-like family member 4 polyglutamylase in PELP1 polyglutamylation and chromatin remodeling in pancreatic cancer cells. Cancer Research 70 4024-4033. (doi:10.1158/0008-5472.CAN-09-4444)

Katayama H \& Sen S 2010 Aurora kinase inhibitors as anticancer molecules. Biochimica et Biophysica Acta 1799 829-839. (doi:10.1016/j.bbagrm.2010.09.004)

Kavallaris M, Kuo DY, Burkhart CA, Regl DL, Norris MD, Haber M \& Horwitz SB 1997 Taxol-resistant epithelial ovarian tumors are associated with altered expression of specific beta-tubulin isotypes. http://erc.endocrinology-journals.org

DOI: $10.1530 /$ ERC-17-0080
C 2017 Society for Endocrinology Printed in Great Britain
Published by Bioscientifica Ltd 
Journal of Clinical Investigation 100 1282-1293. (doi:10.1172/ JCI119642)

Kavallaris M, Tait AS, Walsh BJ, He L, Horwitz SB, Norris MD \& Haber M 2001 Multiple microtubule alterations are associated with Vinca alkaloid resistance in human leukemia cells. Cancer Research $\mathbf{6 1}$ 5803-5809.

Keen N \& Taylor S 2004 Aurora-kinase inhibitors as anticancer agents. Nature Reviews Cancer 4 927-936. (doi:10.1038/nrc1502)

Kienitz A, Vogel C, Morales I, Muller R \& Bastians H 2005 Partial downregulation of MAD1 causes spindle checkpoint inactivation and aneuploidy, but does not confer resistance towards taxol. Oncogene 24 4301-4310. (doi:10.1038/sj.onc.1208589)

Komlodi-Pasztor E, Sackett DL \& Fojo AT 2012 Inhibitors targeting mitosis: tales of how great drugs against a promising target were brought down by a flawed rationale. Clinical Cancer Research 18 51-63. (doi:10.1158/1078-0432.CCR-11-0999)

Kops GJ, Foltz DR \& Cleveland DW 2004 Lethality to human cancer cells through massive chromosome loss by inhibition of the mitotic checkpoint. PNAS 101 8699-8704. (doi:10.1073/pnas.0401142101)

Kops GJ, Weaver BA \& Cleveland DW 2005 On the road to cancer: aneuploidy and the mitotic checkpoint. Nature Reviews Cancer $\mathbf{5}$ 773-785. (doi:10.1038/nrc1714)

Krenn V \& Musacchio A 2015 The aurora B kinase in chromosome bi-orientation and spindle checkpoint signaling. Frontiers in Oncology 5 225. (doi:10.3389/fonc.2015.00225)

Kwiatkowski N, Jelluma N, Filippakopoulos P, Soundararajan M, Manak MS, Kwon M, Choi HG, Sim T, Deveraux QL, Rottmann S, et al. 2010 Smallmolecule kinase inhibitors provide insight into Mps1 cell cycle function. Nature Chemical Biology 6 359-368. (doi:10.1038/nchembio.345)

Lafanechere L, Courtay-Cahen C, Kawakami T, Jacrot M, Rudiger M, Wehland J, Job D \& Margolis RL 1998 Suppression of tubulin tyrosine ligase during tumor growth. Journal of Cell Science $\mathbf{1 1 1}$ 171-181.

Lapenna S \& Giordano A 2009 Cell cycle kinases as therapeutic targets for cancer. Nature Reviews Drug Discovery 8 547-566. (doi:10.1038/ $\operatorname{nrd} 2907)$

Lee YC, Huang CC, Lin DY, Chang WC \& Lee KH 2015 Overexpression of centromere protein $\mathrm{K}$ (CENPK) in ovarian cancer is correlated with poor patient survival and associated with predictive and prognostic relevance. PeerJ 3 e1386. (doi:10.7717/peerj.1386)

Li F, Ackermann EJ, Bennett CF, Rothermel AL, Plescia J, Tognin S, Villa A, Marchisio PC \& Altieri DC 1999 Pleiotropic cell-division defects and apoptosis induced by interference with survivin function. Nature Cell Biology 1 461-466. (doi:10.1038/70242)

Li L, Yang L, Scudiero DA, Miller SA, Yu ZX, Stukenberg PT, Shoemaker RH \& Kotin RM 2007a Development of recombinant adenoassociated virus vectors carrying small interfering RNA (shHec1)mediated depletion of kinetochore Hec1 protein in tumor cells. Gene Therapy 14 814-827. (doi:10.1038/sj.gt.3302933)

Li Y, Tanaka K, Li X, Okada T, Nakamura T, Takasaki M, Yamamoto S, Oda Y, Tsuneyoshi M \& Iwamoto Y 2007b Cyclin-dependent kinase inhibitor, flavopiridol, induces apoptosis and inhibits tumor growth in drug-resistant osteosarcoma and Ewing's family tumor cells. International Journal of Cancer 121 1212-1218. (doi:10.1002/ijc.22820)

Li Y, Zhu Z, Zhang S, Yu D, Yu H, Liu L, Cao X, Wang L, Gao H \& Zhu M 2011 ShRNA-targeted centromere protein A inhibits hepatocellular carcinoma growth. PLOS ONE 6 e17794. (doi:10.1371/journal. pone.0017794)

Li J, Xuan JW, Khatamianfar V, Valiyeva F, Moussa M, Sadek A, Yang BB, Dong BJ, Huang YR \& Gao WQ 2014 SKA1 overexpression promotes centriole over-duplication, centrosome amplification and prostate tumourigenesis. Journal of Pathology 234 178-189.

Lin JP, Yang JS, Lee JH, Hsieh WT \& Chung JG 2006 Berberine induces cell cycle arrest and apoptosis in human gastric carcinoma SNU-5 cell line. World Journal of Gastroenterology 12 21-28. (doi:10.3748/ wjg.v12.i1.21)
Lingle WL, Lutz WH, Ingle JN, Maihle NJ \& Salisbury JL 1998 Centrosome hypertrophy in human breast tumors: implications for genomic stability and cell polarity. PNAS 95 2950-2955. (doi:10.1073/pnas.95.6.2950)

Liu D, Vleugel M, Backer CB, Hori T, Fukagawa T, Cheeseman IM \& Lampson MA 2010 Regulated targeting of protein phosphatase 1 to the outer kinetochore by KNL1 opposes Aurora B kinase. Journal of Cell Biology 188 809-820. (doi:10.1083/jcb.201001006)

Lu LY \& Yu X 2009 The balance of Polo-like kinase 1 in tumorigenesis. Cell Division 4 4. (doi:10.1186/1747-1028-4-4)

Maiato H, Gomes AM, Sousa F \& Barisic M 2017 Mechanisms of chromosome congression during mitosis. Biology 6 13. (doi:10.3390/ biology6010013)

Majid S, Dar AA, Saini S, Chen Y, Shahryari V, Liu J, Zaman MS, Hirata H, Yamamura S, Ueno K, et al. 2010 Regulation of minichromosome maintenance gene family by microRNA-1296 and genistein in prostate cancer. Cancer Research 70 2809-2818. (doi:10.1158/00085472.CAN-09-4176)

Malumbres M 2011 Physiological relevance of cell cycle kinases. Physiological Reviews 91 973-1007. (doi:10.1152/physrev.00025.2010)

Manchado E, Guillamot M, de Carcer G, Eguren M, Trickey M, GarciaHiguera I, Moreno S, Yamano H, Canamero M \& Malumbres M 2010 Targeting mitotic exit leads to tumor regression in vivo: modulation by Cdk1, Mastl, and the PP2A/B55alpha,delta phosphatase. Cancer Cell 18 641-654. (doi:10.1016/j.ccr.2010.10.028)

Manchado E, Guillamot M \& Malumbres M 2012 Killing cells by targeting mitosis. Cell Death and Differentiation 19 369-377. (doi:10.1038/cdd.2011.197)

Mao Y, Abrieu A \& Cleveland DW 2003 Activating and silencing the mitotic checkpoint through CENP-E-dependent activation/inactivation of BubR1. Cell 114 87-98. (doi:10.1016/S0092-8674(03)00475-6)

Margolis RL \& Wilson L 1978 Opposite end assembly and disassembly of microtubules at steady state in vitro. Cell 13 1-8. (doi:10.1016/0092-8674(78)90132-0)

Marks PA 2010 The clinical development of histone deacetylase inhibitors as targeted anticancer drugs. Expert Opinion on Investigational Drugs 19 1049-1066. (doi:10.1517/13543784.2010.510514)

Mc Gee MM 2015 Targeting the mitotic catastrophe signaling pathway in cancer. Mediators of Inflammation 2015 article ID 146282. (doi:10.1155/2015/146282)

McAinsh AD \& Meraldi P 2011 The CCAN complex: linking centromere specification to control of kinetochore-microtubule dynamics. Seminars in Cell and Developmental Biology 22 946-952. (doi:10.1016/j.semcdb.2011.09.016)

McCann MJ, Rowland IR \& Roy NC 2014 The anti-proliferative effects of enterolactone in prostate cancer cells: evidence for the role of DNA licencing genes, mi-R106b cluster expression, and PTEN dosage. Nutrients 6 4839-4855. (doi:10.3390/nu6114839)

McGovern SL, Qi Y, Pusztai L, Symmans WF \& Buchholz TA 2012 Centromere protein-A, an essential centromere protein, is a prognostic marker for relapse in estrogen receptor-positive breast cancer. Breast Cancer Research 14 R72. (doi:10.1186/bcr3181)

McMillen BD, Aponte MM, Liu Z, Helenowski IB, Scholtens DM, Buttin BM \& Wei JJ 2012 Expression analysis of MIR182 and its associated target genes in advanced ovarian carcinoma. Modern Pathology 25 1644-1653. (doi:10.1038/modpathol.2012.118)

Meng QC, Wang HC, Song ZL, Shan ZZ, Yuan Z, Zheng Q \& Huang XY 2015 Overexpression of NDC80 is correlated with prognosis of pancreatic cancer and regulates cell proliferation. American Journal of Cancer Research 5 1730-1740.

Mistry SJ \& Atweh GF 2002 Role of stathmin in the regulation of the mitotic spindle: potential applications in cancer therapy. Mount Sinai Journal of Medicine 69 299-304.

Mistry SJ, Bank A \& Atweh GF 2005 Targeting stathmin in prostate cancer. Molecular Cancer Therapeutics 4 1821-1829. (doi:10.1158/1535-7163.MCT-05-0215) 
Mitchison TJ 1988 Microtubule dynamics and kinetochore function in mitosis. Annual Review of Cell Biology 4 527-549. (doi:10.1146/ annurev.cb.04.110188.002523)

Mitchison TJ 2012 The proliferation rate paradox in antimitotic chemotherapy. Molecular Biology of the Cell 23 1-6. (doi:10.1091/ mbc.E10-04-0335)

Mitchison T \& Kirschner M 1984 Dynamic instability of microtubule growth. Nature 312 237-242. (doi:10.1038/312237a0)

Mollinedo F \& Gajate C 2003 Microtubules, microtubule-interfering agents and apoptosis. Apoptosis 8 413-450. (doi:10.1023/A:1025513106330)

Mountain V, Simerly C, Howard L, Ando A, Schatten G \& Compton DA 1999 The kinesin-related protein, HSET, opposes the activity of Eg5 and cross-links microtubules in the mammalian mitotic spindle. Journal of Cell Biology 147 351-366. (doi:10.1083/jcb.147.2.351)

Mozzetti S, Ferlini C, Concolino P, Filippetti F, Raspaglio G, Prislei S, Gallo D, Martinelli E, Ranelletti FO, Ferrandina G, et al. 2005 Class III beta-tubulin overexpression is a prominent mechanism of paclitaxel resistance in ovarian cancer patients. Clinical Cancer Research 11 298-305.

Mukherji M, Bell R, Supekova L, Wang Y, Orth AP, Batalov S, Miraglia L, Huesken D, Lange J, Martin C, et al. 2006 Genome-wide functional analysis of human cell-cycle regulators. PNAS 103 14819-14824. (doi:10.1073/pnas.0604320103)

Mukhtar E, Adhami VM \& Mukhtar H 2014 Targeting microtubules by natural agents for cancer therapy. Molecular Cancer Therapeutics 13 275-284. (doi:10.1158/1535-7163.MCT-13-0791)

Nishidate T, Katagiri T, Lin ML, Mano Y, Miki Y, Kasumi F, Yoshimoto M, Tsunoda T, Hirata K \& Nakamura Y 2004 Genome-wide geneexpression profiles of breast-cancer cells purified with laser microbeam microdissection: identification of genes associated with progression and metastasis. International Journal of Oncology $\mathbf{2 5}$ 797-819. (doi:10.3892/ijo.25.4.797)

Nogales E 2001 Structural insight into microtubule function. Annual Review of Biophysics and Biomolecular Structure 30 397-420. (doi:10.1146/annurev.biophys.30.1.397)

Nogawa M, Yuasa T, Kimura S, Tanaka M, Kuroda J, Sato K, Yokota A, Segawa H, Toda Y, Kageyama S, et al. 2005 Intravesical administration of small interfering RNA targeting PLK-1 successfully prevents the growth of bladder cancer. Journal of Clinical Investigation 115 978-985. (doi:10.1172/JCI23043)

Oakley BR, Paolillo V \& Zheng Y 2015 gamma-Tubulin complexes in microtubule nucleation and beyond. Molecular Biology of the Cell $\mathbf{2 6}$ 2957-2962. (doi:10.1091/mbc.E14-11-1514)

Ono T, Fang Y, Spector DL \& Hirano T 2004 Spatial and temporal regulation of Condensins I and II in mitotic chromosome assembly in human cells. Molecular Biology of the Cell 15 3296-3308. (doi:10.1091/mbc.E04-03-0242)

Orticello M, Fiore M, Totta P, Desideri M, Barisic M, Passeri D, Lenzi J, Rosa A, Orlandi A, Maiato H, et al. 2015 N-terminus-modified Hec1 suppresses tumour growth by interfering with kinetochoremicrotubule dynamics. Oncogene 34 3325-3335. (doi:10.1038/ onc.2014.265)

Pai SI, Lin YY, Macaes B, Meneshian A, Hung CF \& Wu TC 2006 Prospects of RNA interference therapy for cancer. Gene Therapy $\mathbf{1 3}$ 464-477. (doi:10.1038/sj.gt.3302694)

Park F 2007 Lentiviral vectors: are they the future of animal transgenesis? Physiological Genomics 31 159-173. (doi:10.1152/ physiolgenomics.00069.2007)

Penna SP, Henriques JAP \& Bonatto D 2017 Anti-mitotic agents: Are they emerging molecules for cancer treatment? Pharmacology and Therapeutics 173 67-82. (doi:10.1016/j.pharmthera.2017.02.007)

Petretti C, Savoian M, Montembault E, Glover DM, Prigent C \& Giet R 2006 The PITSLRE/CDK11p58 protein kinase promotes centrosome maturation and bipolar spindle formation. EMBO Reports 7 418-424. (doi:10.1038/sj.embor.7400639)
Petropoulou C, Kotantaki P, Karamitros D \& Taraviras S 2008 Cdt1 and Geminin in cancer: markers or triggers of malignant transformation? Frontiers in Bioscience 13 4485-4494. (doi:10.2741/3018)

Poruchynsky MS, Giannakakou P, Ward Y, Bulinski JC, Telford WG, Robey RW \& Fojo T 2001 Accompanying protein alterations in malignant cells with a microtubule-polymerizing drug-resistance phenotype and a primary resistance mechanism. Biochemical Pharmacology 62 1469-1480. (doi:10.1016/S0006-2952(01)00804-8)

Pulipati NR, Jin Q, Liu X, Sun B, Pandey MK, Huber JP, Ding W \& Mulder KM 2011 Overexpression of the dynein light chain km23-1 in human ovarian carcinoma cells inhibits tumor formation in vivo and causes mitotic delay at prometaphase/metaphase. International Journal of Cancer 129 553-564. (doi:10.1002/ijc.25954)

Qin X, Yuan B, Xu X, Huang H \& Liu Y 2013 Effects of short interfering RNA-mediated gene silencing of SKA1 on proliferation of hepatocellular carcinoma cells. Scandinavian Journal of Gastroenterology 48 1324-1332. (doi:10.3109/00365521.2013.828774)

Qiu JJ, Guo JJ, Lv TJ, Jin HY, Ding JX, Feng WW, Zhang Y \& Hua KQ 2013 Prognostic value of centromere protein-A expression in patients with epithelial ovarian cancer. Tumor Biology 34 2971-2975. (doi:10.1007/s13277-013-0860-6)

Ranganathan S, Dexter DW, Benetatos CA, Chapman AE, Tew KD \& Hudes GR 1996 Increase of beta(III)- and beta(IVa)-tubulin isotopes in human prostate carcinoma cells as a result of estramustine resistance. Cancer Research 56 2584-2589.

Rath O \& Kozielski F 2012 Kinesins and cancer. Nature Reviews Cancer 12 527-539. (doi:10.1038/nrc3310)

Reagan-Shaw S \& Ahmad N 2005 Polo-like kinase (Plk) 1 as a target for prostate cancer management. IUBMB Life 57 677-682. (doi:10.1080/15216540500305910)

Rialland M, Sola F \& Santocanale C 2002 Essential role of human CDT1 in DNA replication and chromatin licensing. Journal of Cell Science 115 1435-1440.

Rice L, Waters CE, Eccles J, Garside H, Sommer P, Kay P, Blackhall FH, Zeef L, Telfer B, Stratford I, et al. 2008 Identification and functional analysis of SKA2 interaction with the glucocorticoid receptor. Journal of Endocrinology 198 499-509. (doi:10.1677/JOE-08-0019)

Ricke RM, van Ree JH \& van Deursen JM 2008 Whole chromosome instability and cancer: a complex relationship. Trends in Genetics $\mathbf{2 4}$ 457-466. (doi:10.1016/j.tig.2008.07.002)

Rusan NM, Fagerstrom CJ, Yvon AM \& Wadsworth P 2001 Cell cycledependent changes in microtubule dynamics in living cells expressing green fluorescent protein-alpha tubulin. Molecular Biology of the Cell 12 971-980. (doi:10.1091/mbc.12.4.971)

Salmela AL \& Kallio MJ 2013 Mitosis as an anti-cancer drug target. Chromosoma 122 431-449. (doi:10.1007/s00412-013-0419-8)

Sankaran S, Starita LM, Groen AC, Ko MJ \& Parvin JD 2005 Centrosomal microtubule nucleation activity is inhibited by BRCA1-dependent ubiquitination. Molecular and Cellular Biology 25 8656-8668. (doi:10.1128/MCB.25.19.8656-8668.2005)

Santaguida S, Tighe A, D'Alise AM, Taylor SS \& Musacchio A 2010 Dissecting the role of MPS1 in chromosome biorientation and the spindle checkpoint through the small molecule inhibitor reversine. Journal of Cell Biology 190 73-87. (doi:10.1083/jcb.201001036)

Sawin KE, LeGuellec K, Philippe M \& Mitchison TJ 1992 Mitotic spindle organization by a plus-end-directed microtubule motor. Nature 359 540-543. (doi:10.1038/359540a0)

Saxton WM, Stemple DL, Leslie RJ, Salmon ED, Zavortink M \& McIntosh JR 1984 Tubulin dynamics in cultured mammalian cells. Journal of Cell Biology 99 2175-2186. (doi:10.1083/jcb.99.6.2175)

Schaar BT, Chan GK, Maddox P, Salmon ED \& Yen TJ 1997 CENP-E function at kinetochores is essential for chromosome alignment. Journal of Cell Biology 139 1373-1382. (doi:10.1083/jcb.139.6.1373)

Schafer-Hales K, Iaconelli J, Snyder JP, Prussia A, Nettles JH, El-Naggar A, Khuri FR, Giannakakou P \& Marcus AI 2007 Farnesyl transferase inhibitors impair chromosomal maintenance in cell lines and human 
tumors by compromising CENP-E and CENP-F function. Molecular Cancer Therapeutics 6 1317-1328. (doi:10.1158/1535-7163.MCT-06-0703)

Schmidt M \& Bastians H 2007 Mitotic drug targets and the development of novel anti-mitotic anticancer drugs. Drug Resistance Updates 10 162-181. (doi:10.1016/j.drup.2007.06.003)

Schmidt JC, Arthanari H, Boeszoermenyi A, Dashkevich NM, WilsonKubalek EM, Monnier N, Markus M, Oberer M, Milligan RA, Bathe M, et al. 2012 The kinetochore-bound Ska1 complex tracks depolymerizing microtubules and binds to curved protofilaments. Developmental Cell 23 968-980. (doi:10.1016/j.devcel.2012.09.012)

Schmit TL \& Ahmad N 2007 Regulation of mitosis via mitotic kinases: new opportunities for cancer management. Molecular Cancer Therapeutics 6 1920-1931. (doi:10.1158/1535-7163.MCT-06-0781)

Sen S, Zhou H \& White RA 1997 A putative serine/threonine kinase encoding gene BTAK on chromosome $20 \mathrm{q} 13$ is amplified and overexpressed in human breast cancer cell lines. Oncogene 14 2195-2200. (doi:10.1038/sj.onc.1201065)

Seo J, Chung YS, Sharma GG, Moon E, Burack WR, Pandita TK \& Choi K 2005 Cdt1 transgenic mice develop lymphoblastic lymphoma in the absence of p53. Oncogene 24 8176-8186.

Sethi G, Pathak HB, Zhang H, Zhou Y, Einarson MB, Vathipadiekal V, Gunewardena S, Birrer MJ \& Godwin AK 2012 An RNA interference lethality screen of the human druggable genome to identify molecular vulnerabilities in epithelial ovarian cancer. PLOS ONE 7 e47086. (doi:10.1371/journal.pone.0047086)

Shanmugam R, Kusumanchi P, Cheng L, Crooks P, Neelakantan S Matthews W, Nakshatri H \& Sweeney CJ 2010 A water-soluble parthenolide analogue suppresses in vivo prostate cancer growth by targeting NFkappaB and generating reactive oxygen species. Prostate 70 1074-1086. (doi:10.1002/pros.21141)

Sirajuddin M, Rice LM \& Vale RD 2014 Regulation of microtubule motors by tubulin isotypes and post-translational modifications. Nature Cell Biology 16 335-344. (doi:10.1038/ncb2920)

Slee RB, Grimes BR, Bansal R, Gore J, Blackburn C, Brown L, Gasaway R, Jeong J, Victorino J, March KL, et al. 2014 Selective inhibition of pancreatic ductal adenocarcinoma cell growth by the mitotic MPS1 kinase inhibitor NMS-P715. Molecular Cancer Therapeutics 13 307-315. (doi:10.1158/1535-7163.MCT-13-0324)

Smolders L \& Teodoro JG 2011 Targeting the anaphase promoting complex: common pathways for viral infection and cancer therapy. Expert Opinion on Therapeutic Targets 15 767-780. (doi:10.1517/14728222.2011.558008)

Smoter M, Bodnar L, Duchnowska R, Stec R, Grala B \& Szczylik C 2011 The role of Tau protein in resistance to paclitaxel. Cancer Chemotherapy and Pharmacology 68 553-557. (doi:10.1007/s00280-011-1696-7)

Sorrentino R, Libertini S, Pallante PL, Troncone G, Palombini L, Bavetsias V, Spalletti-Cernia D, Laccetti P, Linardopoulos S, Chieffi $\mathrm{P}$, et al. 2005 Aurora B overexpression associates with the thyroid carcinoma undifferentiated phenotype and is required for thyroid carcinoma cell proliferation. Journal of Clinical Endocrinology and Metabolism 90 928-935. (doi:10.1210/jc.2004-1518)

Soucek K, Kamaid A, Phung AD, Kubala L, Bulinski JC, Harper RW \& Eiserich JP 2006 Normal and prostate cancer cells display distinct molecular profiles of alpha-tubulin posttranslational modifications. Prostate 66 954-965. (doi:10.1002/pros.20416)

Spankuch-Schmitt B, Bereiter-Hahn J, Kaufmann M \& Strebhardt K $2002 a$ Effect of RNA silencing of polo-like kinase-1 (PLK1) on apoptosis and spindle formation in human cancer cells. Journal of the National Cancer Institute 94 1863-1877. (doi:10.1093/ jnci/94.24.1863)

Spankuch-Schmitt B, Wolf G, Solbach C, Loibl S, Knecht R, Stegmuller M, von Minckwitz G, Kaufmann M \& Strebhardt K 2002b Downregulation of human polo-like kinase activity by antisense oligonucleotides induces growth inhibition in cancer cells. Oncogene 21 3162-3171. (doi:10.1038/sj.onc.1205412)

Still IH, Vince P \& Cowell JK 1999 The third member of the transforming acidic coiled coil-containing gene family, TACC3, maps in $4 \mathrm{p} 16$, close to translocation breakpoints in multiple myeloma, and is upregulated in various cancer cell lines. Genomics 58 165-170. (doi:10.1006/geno.1999.5829)

Strock CJ, Park JI, Nakakura EK, Bova GS, Isaacs JT, Ball DW \& Nelkin BD 2006 Cyclin-dependent kinase 5 activity controls cell motility and metastatic potential of prostate cancer cells. Cancer Research 66 7509-7515. (doi:10.1158/0008-5472.CAN-05-3048)

Sudakin V \& Yen TJ 2007 Targeting mitosis for anti-cancer therapy. BioDrugs 21 225-233. (doi:10.2165/00063030-200721040-00003)

Sun C, Li N, Yang Z, Zhou B, He Y, Weng D, Fang Y, Wu P, Chen P, Yang $\mathrm{X}$, et al. 2013 miR-9 regulation of BRCA1 and ovarian cancer sensitivity to cisplatin and PARP inhibition. Journal of the National Cancer Institute 105 1750-1758. (doi:10.1093/jnci/djt302)

Sun W, Yao L, Jiang B, Guo L \& Wang Q 2014 Spindle and kinetochoreassociated protein 1 is overexpressed in gastric cancer and modulates cell growth. Molecular and Cellular Biochemistry 391 167-174. (doi:10.1007/s11010-014-1999-1)

Sweeney CJ, Mehrotra S, Sadaria MR, Kumar S, Shortle NH, Roman Y, Sheridan C, Campbell RA, Murry DJ, Badve S, et al. 2005 The sesquiterpene lactone parthenolide in combination with docetaxel reduces metastasis and improves survival in a xenograft model of breast cancer. Molecular Cancer Therapeutics 4 1004-1012. (doi:10.1158/1535-7163.MCT-05-0030)

Tanaka TU, Rachidi N, Janke C, Pereira G, Galova M, Schiebel E, Stark MJ \& Nasmyth K 2002 Evidence that the Ipl1-Sli15 (Aurora kinaseINCENP) complex promotes chromosome bi-orientation by altering kinetochore-spindle pole connections. Cell 108 317-329. (doi:10.1016/S0092-8674(02)00633-5)

Tanenbaum ME, Macurek L, Janssen A, Geers EF, Alvarez-Fernandez M \& Medema RH 2009 Kif15 cooperates with eg5 to promote bipolar spindle assembly. Current Biology 19 1703-1711. (doi:10.1016/j.cub.2009.08.027)

Tang NH \& Toda T 2015 MAPping the Ndc80 loop in cancer: a possible link between Ndc80/Hec1 overproduction and cancer formation. Bioessays 37 248-256. (doi:10.1002/bies.201400175)

Tang Q, Staub CM, Gao G, Jin Q, Wang Z, Ding W, Aurigemma RE \& Mulder KM 2002 A novel transforming growth factor-beta receptorinteracting protein that is also a light chain of the motor protein dynein. Molecular Biology of the Cell 13 4484-4496. (doi:10.1091/ mbc.E02-05-0245)

Tannous BA, Kerami M, Van der Stoop PM, Kwiatkowski N, Wang J, Zhou W, Kessler AF, Lewandrowski G, Hiddingh L, Sol N, et al. 2013 Effects of the selective MPS1 inhibitor MPS1-IN-3 on glioblastoma sensitivity to antimitotic drugs. Journal of the National Cancer Institute 105 1322-1331. (doi:10.1093/jnci/djt168)

Tardif KD, Rogers A, Cassiano J, Roth BL, Cimbora DM, McKinnon R, Peterson A, Douce TB, Robinson R, Dorweiler I, et al. 2011 Characterization of the cellular and antitumor effects of MPI-0479605, a small-molecule inhibitor of the mitotic kinase Mps1. Molecular Cancer Therapeutics 10 2267-2275. (doi:10.1158/1535-7163.MCT-11-0453)

Tassone P, Blotta S, Palmieri C, Masciari S, Quaresima B, Montagna M, D'Andrea E, Eramo OP, Migale L, Costanzo F, et al. 2005 Differential sensitivity of BRCA1-mutated HCC1937 human breast cancer cells to microtubule-interfering agents. International Journal of Oncology 26 1257-1263. (doi:10.3892/ijo.26.5.1257)

Tatsuka M, Katayama H, Ota T, Tanaka T, Odashima S, Suzuki F \& Terada Y 1998 Multinuclearity and increased ploidy caused by overexpression of the aurora- and Ipl1-like midbody-associated protein mitotic kinase in human cancer cells. Cancer Research 58 4811-4816.

Tcherniuk S, van Lis R, Kozielski F \& Skoufias DA 2010 Mutations in the human kinesin Eg5 that confer resistance to monastrol and S-tritylL-cysteine in tumor derived cell lines. Biochemical Pharmacology 79 864-872. (doi:10.1016/j.bcp.2009.11.001)

Theriault BL, Pajovic S, Bernardini MQ, Shaw PA \& Gallie BL 2012 Kinesin family member 14: an independent prognostic marker and potential therapeutic target for ovarian cancer. International Journal of Cancer 130 1844-1854. (doi:10.1002/ijc.26189) http://erc.endocrinology-journals.org

DOI: 10.1530/ERC-17-0080
(C) 2017 Society for Endocrinology Printed in Great Britain 
Thiru P, Kern DM, McKinley KL, Monda JK, Rago F, Su KC, Tsinman T, Yarar D, Bell GW \& Cheeseman IM 2014 Kinetochore genes are coordinately upregulated in human tumors as part of a FoxM1related cell division program. Molecular Biology of the Cell $\mathbf{2 5}$ 1983-1994. (doi:10.1091/mbc.E14-03-0837)

Thompson SL \& Compton DA 2011 Chromosomes and cancer cells. Chromosome Research 19 433-444. (doi:10.1007/s10577-010-9179-y)

Tomonaga T, Matsushita K, Yamaguchi S, Oohashi T, Shimada H, Ochiai T, Yoda K \& Nomura F 2003 Overexpression and mistargeting of centromere protein-A in human primary colorectal cancer. Cancer Research 63 3511-3516.

Tooley J \& Stukenberg PT 2011 The Ndc80 complex: integrating the kinetochore's many movements. Chromosome Research 19 377-391. (doi:10.1007/s10577-010-9180-5)

Tran PT, Walker RA \& Salmon ED 1997 A metastable intermediate state of microtubule dynamic instability that differs significantly between plus and minus ends. Journal of Cell Biology 138 105-117. (doi:10.1083/jcb.138.1.105)

Urata YN, Takeshita F, Tanaka H, Ochiya T \& Takimoto M 2015 Targeted knockdown of the kinetochore protein D40/Knl-1 inhibits human cancer in a p53 status-independent manner. Scientific Reports $\mathbf{5}$ 13676. (doi:10.1038/srep13676)

Vallee RB, Varma D \& Dujardin DL 2006 ZW10 function in mitotic checkpoint control, dynein targeting and membrane trafficking: is dynein the unifying theme? Cell Cycle 5 2447-2451. (doi:10.4161/cc.5.21.3395)

Varma D \& Salmon ED 2012 The KMN protein network - chief conductors of the kinetochore orchestra. Journal of Cell Science $\mathbf{1 2 5}$ 5927-5936. (doi:10.1242/jcs.093724)

Varma D, Chandrasekaran S, Sundin LJ, Reidy KT, Wan X, Chasse DA, Nevis KR, DeLuca JG, Salmon ED \& Cook JG 2012 Recruitment of the human Cdt1 replication licensing protein by the loop domain of $\mathrm{Hec} 1$ is required for stable kinetochore-microtubule attachment. Nature Cell Biology 14 593-603. (doi:10.1038/ncb2489)

Veitia R, David S, Barbier P, Vantard M, Gounon P, Bissery MC \& Fellous A 2000 Proteolysis of microtubule associated protein 2 and sensitivity of pancreatic tumours to docetaxel. British Journal of Cancer 83 544-549. (doi:10.1054/bjoc.2000.1294)

Vicente JJ \& Wordeman L 2015 Mitosis, microtubule dynamics and the evolution of kinesins. Experimental Cell Research 334 61-69. (doi:10.1016/j.yexcr.2015.02.010)

Wang X, Li L, Liang Y, Li C, Zhao H, Ye D, Sun M, Jeong LS, Feng Y, Fu S, et al. 2014 Targeting the neddylation pathway to suppress the growth of prostate cancer cells: therapeutic implication for the men's cancer. BioMed Research International 2014974309. (doi:10.1155/2014/974309)

Wasylyk C, Zambrano A, Zhao C, Brants J, Abecassis J, Schalken JA, Rogatsch H, Schaefer G, Pycha A, Klocker H, et al. 2010 Tubulin tyrosine ligase like 12 links to prostate cancer through tubulin posttranslational modification and chromosome ploidy. International Journal of Cancer 127 2542-2553. (doi:10.1002/ijc.25261)

Welburn JP, Vleugel M, Liu D, Yates JR 3rd, Lampson MA, Fukagawa T \& Cheeseman IM 2010 Aurora B phosphorylates spatially distinct targets to differentially regulate the kinetochore-microtubule interface. Molecular Cell 38 383-392. (doi:10.1016/j.molcel.2010.02.034)

Wojcik E, Basto R, Serr M, Scaerou F, Karess R \& Hays T 2001 Kinetochore dynein: its dynamics and role in the transport of the Rough deal checkpoint protein. Nature Cell Biology 3 1001-1007. (doi:10.1038/ncb1101-1001)

Wood KW, Sakowicz R, Goldstein LS \& Cleveland DW 1997 CENP-E is a plus end-directed kinetochore motor required for metaphase chromosome alignment. Cell 91 357-366. (doi:10.1016/S00928674(00)80419-5)
Wood KW, Chua P, Sutton D \& Jackson JR 2008 Centromere-associated protein E: a motor that puts the brakes on the mitotic checkpoint. Clinical Cancer Research 14 7588-7592. (doi:10.1158/1078-0432.CCR-07-4443)

Wood KW, Lad L, Luo L, Qian X, Knight SD, Nevins N, Brejc K, Sutton D, Gilmartin AG, Chua PR, et al. 2010 Antitumor activity of an allosteric inhibitor of centromere-associated protein-E. PNAS 107 5839-5844. (doi:10.1073/pnas.0915068107)

Wright C \& Brooks WS 2013 Overexpression of the kinetochoreassociated proteins SKAP and astrin in human breast cancer. BIOS 84 136-141. (doi:10.1893/0005-3155-84.3.136)

Wu G, Qiu XL, Zhou L, Zhu J, Chamberlin R, Lau J, Chen PL \& Lee WH 2008 Small molecule targeting the Hec1/Nek2 mitotic pathway suppresses tumor cell growth in culture and in animal. Cancer Research 68 8393-8399. (doi:10.1158/0008-5472.CAN-08-1915)

Wu Q, Qian YM, Zhao XL, Wang SM, Feng XJ, Chen XF \& Zhang SH 2012 Expression and prognostic significance of centromere protein A in human lung adenocarcinoma. Lung Cancer 77 407-414. (doi:10.1016/j.lungcan.2012.04.007)

Yang XJ \& Seto E 2008 Lysine acetylation: codified crosstalk with other posttranslational modifications. Molecular Cell 31 449-461. (doi:10.1016/j.molcel.2008.07.002)

Yao X, Abrieu A, Zheng Y, Sullivan KF \& Cleveland DW 2000 CENP-E forms a link between attachment of spindle microtubules to kinetochores and the mitotic checkpoint. Nature Cell Biology 2 484-491. (doi:10.1038/35019518)

Yu Y \& Feng YM 2010 The role of kinesin family proteins in tumorigenesis and progression: potential biomarkers and molecular targets for cancer therapy. Cancer 116 5150-5160. (doi:10.1002/cncr.25461)

Yu L, Shang ZF, Abdisalaam S, Lee KJ, Gupta A, Hsieh JT, Asaithamby A, Chen BP \& Saha D 2016 Tumor suppressor protein DAB2IP participates in chromosomal stability maintenance through activating spindle assembly checkpoint and stabilizing kinetochoremicrotubule attachments. Nucleic Acids Research 44 8842-8854. (doi:10.1093/nar/gkw746)

Zelnak AB 2007 Clinical pharmacology and use of microtubule-targeting agents in cancer therapy. Methods in Molecular Medicine 137 209-234.

Zeng X, Sigoillot F, Gaur S, Choi S, Pfaff KL, Oh DC, Hathaway N, Dimova N, Cuny GD \& King RW 2010 Pharmacologic inhibition of the anaphase-promoting complex induces a spindle checkpointdependent mitotic arrest in the absence of spindle damage. Cancer Cell 18 382-395. (doi:10.1016/j.ccr.2010.08.010)

Zhang C, Zhu C, Chen H, Li L, Guo L, Jiang W \& Lu SH 2010 Kif18A is involved in human breast carcinogenesis. Carcinogenesis $\mathbf{3 1}$ 1676-1684. (doi:10.1093/carcin/bgq134)

Zhang B, Li KY, Chen HY, Pan SD, Jiang LC, Wu YP \& Liu SW $2013 a$ Spindle and kinetochore associated complex subunit 1 regulates the proliferation of oral adenosquamous carcinoma CAL-27 cells in vitro. Cancer Cell International 13 83. (doi:10.1186/1475-2867-13-83)

Zhang D, Chen ZG, Liu SH, Dong ZQ, Dalin M, Bao SS, Hu YW \& Wei FC $2013 b$ Galectin-3 gene silencing inhibits migration and invasion of human tongue cancer cells in vitro via downregulating betacatenin. Acta Pharmacologica Sinica 34 176-184. (doi:10.1038/ aps.2012.150)

Zhang W, Mao JH, Zhu W, Jain AK, Liu K, Brown JB \& Karpen GH 2016 Centromere and kinetochore gene misexpression predicts cancer patient survival and response to radiotherapy and chemotherapy. Nature Communication 7 12619. (doi:10.1038/ncomms12619)

Zhu C, Zhao J, Bibikova M, Leverson JD, Bossy-Wetzel E, Fan JB, Abraham RT \& Jiang W 2005 Functional analysis of human microtubule-based motor proteins, the kinesins and dyneins, in mitosis/cytokinesis using RNA interference. Molecular Biology of the Cell 16 3187-3199. (doi:10.1091/mbc.E05-02-0167)

Received in final form 2 June 2017

Accepted 14 June 2017

Accepted Preprint published online 14 June 2017

Published by Bioscientifica Ltc. http://erc.endocrinology-journals.org

DOI: 10.1530/ERC-17-0080
๑ 2017 Society for Endocrinology Printed in Great Britain 